UCRL-ID-130064

\title{
Waste Package Degradation Expert Elicitation Panel: Input on the Corrosion of CRM Alloy C-22
}

\author{
Joseph C. Farmer
}

February 26, 1998

This is an informal report intended primarily for internal or limited external distribution. The opinions and conclusions stated are those of the author and may or may not be those of the Laboratory.

Work performed under the auspices of the U.S. Department of Energy by the Lawrence Livermore National Laboratory under Contract W-7405-Eng-48. 


\section{DISCLAIMER}

This document was prepared as an account of work sponsored by an agency of the United States Government. Neither the United States Government nor the University of California nor any of their employees, makes any warranty, express or implied, or assumes any legal liability or responsibility for the accuracy, completeness, or usefulness of any information, apparatus, product, or process disclosed, or represents that its use would not infringe privately owned rights. Reference herein to any specific commercial product, process, or service by trade name, trademark, manufacturer, or otherwise, does not necessarily constitute or imply its endorsement, recommendation, or favoring by the United States Government or the University of California. The views and opinions of authors expressed herein do not necessarily state or reflect those of the United States Government or the University of California, and shall not be used for advertising or product endorsement purposes.

This report has been reproduced directly from the best available copy.

Available to DOE and DOE contractors from the Office of Scientific and Technical Information

P.O. Box 62, Oak Ridge, TN 37831

Prices available from (615) 576-8401, FTS 626-8401

Available to the public from the

National Technical Information Service

U.S. Department of Commerce

5285 Port Royal Rd.,

Springfield, VA 22161 
Draft Rev 5 - J. C. Farmer, LLNL, YMP WP Degradation, Expert Elicitation Panel, Feb 26, 1998

\title{
WASTE PACKAGE DEGRADATION EXPERT ELICITATION PANEL: INPUT ON THE CORROSION OF CRM ALLOY C-22
}

\author{
Joseph C. Farmer \\ University of California \\ Lawrence Livermore National Laboratory \\ 7000 East Avenue or P.O. Box 808 \\ Livermore, California 94550 \\ Telephone 510-423-6574 \\ Fax 510-423-2086 \\ Secretary 510-422-9279 (Nan Poggio)
}

February 26, 1998

\section{ANTICIPATED ENVIRONMENTS}

The overall electrolyte concentration in the NFE environment is expected to be somewhere between $1 \mathrm{X}$ and saturated J-13 well water. This covers more than three orders-of-magnitude in chloride anion concentration. The $\mathrm{pH}$ of this solution is expected to be somewhere between 5 and 10 . Exposed patches of the CRM could see this environment.

The $\mathrm{pH}$ in the crevice can be acidified due to the hydrolysis of dissolved polyvalent cations, such as $\mathrm{Fe}^{2+}$. As discussed by Oldfield and Sutton, metal ions produced by anodic dissolution are assumed to undergo the following hydrolysis reactions [J. W. Oldfield. W. H. Sutton, "Crevice Corrosion of Stainless Steels: I. A Mathematical Model," British Corrosion Journal, Vol. 13, No. 1, 1978, pp. 1322]:

$$
\begin{aligned}
& \mathrm{Fe}^{2+}+\mathrm{H}_{2} \mathrm{O} \longleftrightarrow \mathrm{K}_{31} \mathrm{Fe}(\mathrm{OH})^{+}+\mathrm{H}^{+} \\
& \mathrm{Fe}^{3+}+\mathrm{H}_{2} \mathrm{O} \underset{\mathrm{K}_{+1}}{\longrightarrow} \mathrm{Fe}(\mathrm{OH})^{2+}+\mathrm{H}^{+} \\
& \mathrm{Ni}^{2+}+\mathrm{H}_{2} \mathrm{O} \underset{\mathrm{K}_{31}}{\longrightarrow} \mathrm{Ni}(\mathrm{OH})^{+}+\mathrm{H}^{+} \\
& \mathrm{Cr}^{3+}+\mathrm{H}_{2} \mathrm{O} \underset{K_{11}}{\longrightarrow} \mathrm{Cr}(\mathrm{OH})^{2+}+\mathrm{H}^{+} \\
& \mathrm{Cr}(\mathrm{OH})^{2+}+\mathrm{H}_{2} \mathrm{O} \underset{\mathrm{K}_{12}}{\longrightarrow} \mathrm{Cr}(\mathrm{OH})_{2}^{+}+\mathrm{H}^{+}
\end{aligned}
$$

These reactions have also been considered in a crevice corrosion model published by the NRC [J. C. Walton, S. K. Kalandros, "TWITCH - A Model for Transient Diffusion, Electromigration, and Chemical Reaction in One Dimension," Center for Nuclear Waste Regulatory Analyses, San Antonio, TX, CNWRA 92-019, 1992]. The range of $\mathrm{pH}$ expected under a worst-case scenario (no precipitation of $\mathrm{FeCO}_{3}$; no leakage of dissolved metal or acid out of the crevice; no $\mathrm{pH}$ buffers; etc.) is illustrated by the data of Jones et al., as shown in Table 1 [D. A. Jones, B. E. Wilde, "Galvanic Reactions During Localized Corrosion on Stainless Steel," Corrosion Science, Vol. 18, 1978, pp. 631-643].

Table 1. Suppression of $\mathrm{pH}$ by Hydrolysis Reactions in $\mathrm{FeCl}_{2}, \mathrm{NiCl}_{2}$, and $\mathrm{CrCl}_{3}\left(25^{\circ} \mathrm{C}\right)$.

\begin{tabular}{|c|c|c|c|}
\hline Salt & $1 \mathrm{~N}$ & $3 \mathrm{~N}$ & Saturated \\
\hline $\mathrm{FeCl}_{2}$ & 2.1 & 0.8 & 0.2 \\
\hline $\mathrm{NiCl}_{2}$ & 3.0 & 2.7 & 2.7 \\
\hline $\mathrm{CrCl}_{3}$ & 1.1 & -0.3 & -1.4 \\
\hline
\end{tabular}


The lowest possible $\mathrm{pH}$ values expected with $\mathrm{FeCl}_{2}$ solutions at $25^{\circ} \mathrm{C}$ is 0.2 . The $\mathrm{pH}$ levels measured in $\mathrm{FeCl}_{3}$ solutions by Francis Wang are shown in Table 2.

Table 2. Suppression of $\mathrm{pH}$ by Hydrolysis Reactions in $\mathrm{FeCl}$ Solutions $\left(25^{\circ} \mathrm{C}\right)$.

\begin{tabular}{|l|l|}
\hline $\mathrm{FeCl}_{3}$ (wt. \%) & $\mathrm{pH}$ \\
\hline 1 & 1.92 \\
\hline 2 & 1.83 \\
\hline 3 & 1.71 \\
\hline 4 & 1.63 \\
\hline 10 & 0.70 \\
\hline
\end{tabular}

More realistic estimates must include transport of $\mathrm{Fe}^{2+}$ and other species out of the crevice, limitations on the rate of $\mathrm{Cl}^{-}$transport into the crevice, $\mathrm{pH}$ buffer effects due to other ion, and precipitation of hydrolyzable $\mathrm{Fe}^{2+}$ by carbonate. Such effects will tend to make the $\mathrm{pH}$ higher than these extreme values based upon thermodynamic equilibrium. A transport model for crevice corrosion has been developed by two of members of this Expert Elicitation Panel and was used to predict a $\mathrm{pH}$ of roughly 2.8-3.2 during the attack of Alloy 625 [J. C. Farmer, R. D. McCright, "Crevice Corrosion and Pitting of High-Level Waste Containers: Integration of Deterministic and Probabilistic Models," Paper No. 160, Annual Meeting of the National Association of Corrosion Engineers (NACE), Corrosion 98, San Diego, CA March 22-27, 1998].

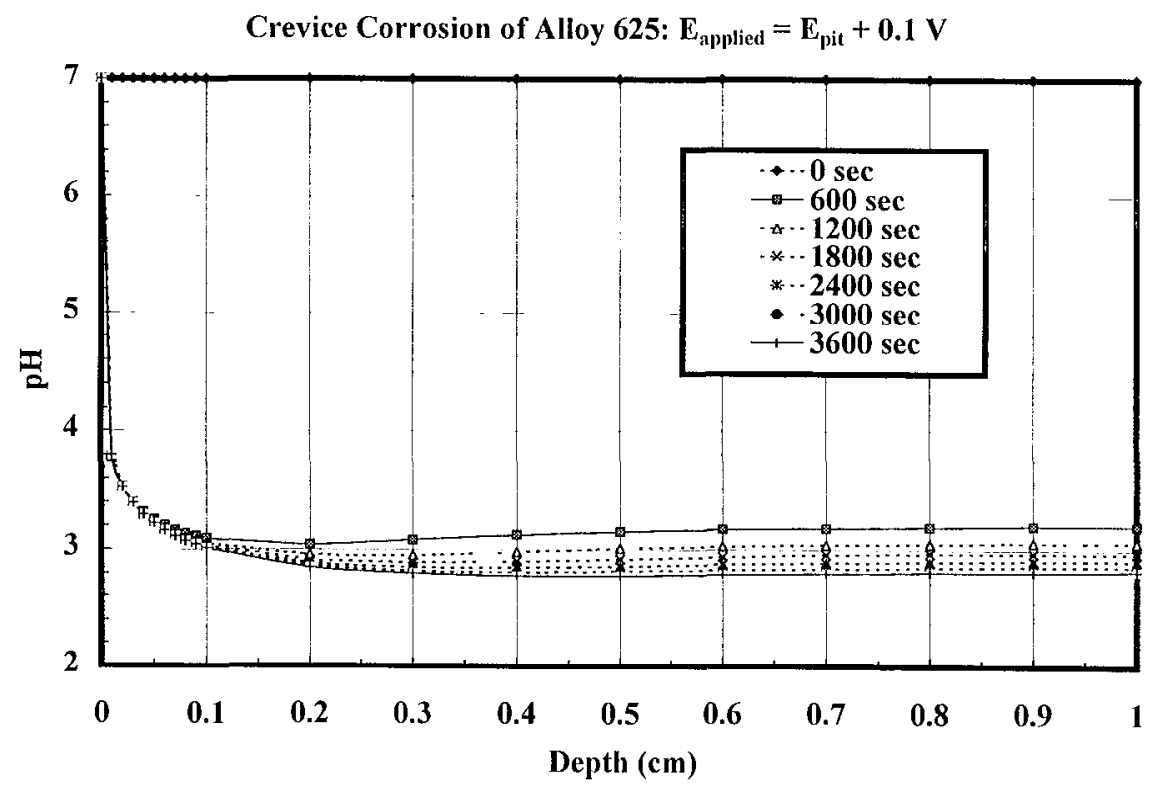

Figure 1. Prediction of transport-limited pH suppresion in crevice during attack of Alloy 625. The potential assumed as a boundary condition at the crevice mouth (applied potential) was fixed at a level $100 \mathrm{mV}$ more anodic that the critical pitting potential of Alloy 625.

During the Appendix 7 Meeting, the range of expected values given by the NRC Center are:

A. NFE $5<\mathrm{pH}<10$ 
Draft Rev. 5 -.J. C. Farmer, LLNL, YMP WP Degradation, Expert Elicitation Panel, Feb. 26, 1998

B. Crevice - Before Localized Corrosion of CRM: $3<\mathrm{pH}<5$. Likely case, since this will occur near Ecorr of A516. Due to hydrolysis of Fe alone. Depends upon transport and crevice geometry.

C. Crevice - After Localized Corrosion of CRM: $-1<\mathrm{pH}<3$. Requires potential above repassivation potential, and considered very unlikely. Due to hydrolysis of other dissolved metals, such as $\mathrm{Cr}$ and Mo. Depends on transport and crevice geometry.

It is believed that the electrochemical potential at the mouth of the crevice will be somewhere between the mixed potential of A516 Gr 12 and Alloy C-22, in either concentrated J-13 or concentrated (10 wt. $\% \mathrm{FeCl}_{3}$ ). See Table 3 .

Table 3 Expected Electrochemical Potentials in Repository-Based on Measurements.

\begin{tabular}{|l|c|c|c|c|c|}
\hline Case & A & B & C & D & E \\
\hline $\mathrm{T}\left({ }^{\circ} \mathrm{C}\right)$ & 90 & 90 & 90 & 90 & 90 \\
\hline $\mathrm{NaCl}$ (wt. \%) & 10 & 1 & 0 & 0 & 5 \\
\hline $\mathrm{FeCl}_{3}$ (wt. \%) & 0 & 0 & 0.6 & 3.1 & 0 \\
\hline $\mathrm{pH}$ & 6.8 & 2.7 & 2.14 & 1.72 & 2.7 \\
\hline Radiolysis & No & No & No & No & No \\
\hline Deaerated & No & Yes & Yes & Yes & No \\
\hline $\mathrm{E}_{\text {corı }}(\mathrm{mV}$ vs. SHE): A516 Gr 12 & & & & & -520 \\
\hline $\mathrm{E}_{\text {corr }}(\mathrm{mV}$ vs. SHE): C-22 & -24 & -29 & +661 & +714 & \\
\hline $\mathrm{E}_{\text {pit }}(\mathrm{mV}$ vs. SHE): C-22 & +442 & +758 & +905 & +889 & $>+730$ \\
\hline $\mathrm{E}_{\text {pass }}(\mathrm{mV}$ vs. SHE): C-22 & +550 & +793 & +857 & +896 & $>+730$ \\
\hline Above Threshold Potential & No & No & No & No & No \\
\hline
\end{tabular}

In the absence of $\mathrm{FeCl}_{3}$, which is a product of the CAM corrosion, the greatest mixed potential expected is somewhere between -520 and $-29 \mathrm{mV}$ vs. SHE at $90^{\circ} \mathrm{C}$. With $\mathrm{FeCl}_{3}$ at 10 wt. \%, potentials as high as $+714 \mathrm{mV}$ vs. SHE have been observed. Since the observed mixed potential never exceeded the pitting potential or the repassivation potential, localized attack is not be expected. This interpretation is consistent with the interpretation of Cragnolino [G. A. Cragnolino, DOE/NRC Appendix 7 Mecting, Livermore, CA, Fcbruary, 1998]. These obscrvations do not account for the effects of gamma radiolysis and other effects.

From transport modeling of corrosion in the CAM-CRM crevice, it is known that the electrochemical potential inside the crevice is less anodic (less severe) than the potential established or applied at the mouth of the crevice [J. C. Farmer, R. D. McCright, "Crevice Corrosion and Pitting of High-Level Waste Containers: Integration of Deterministic and Probabilistic Models," Paper No. 160, Annual Meeting of the National $\Lambda$ ssociation of Corrosion Engineers (NACE), Corrosion 98, San Diego, C $\Lambda$ March 22-27, 1998]. This is due to ohmic drop along the length of the crevice. Consequently, any estimate of corrosion rate based on the electrochemical potential at the crevice mouth, coupled with the assumption of suppressed $\mathrm{pH}$ and elevated chloride inside the crevice, should be conservative. 


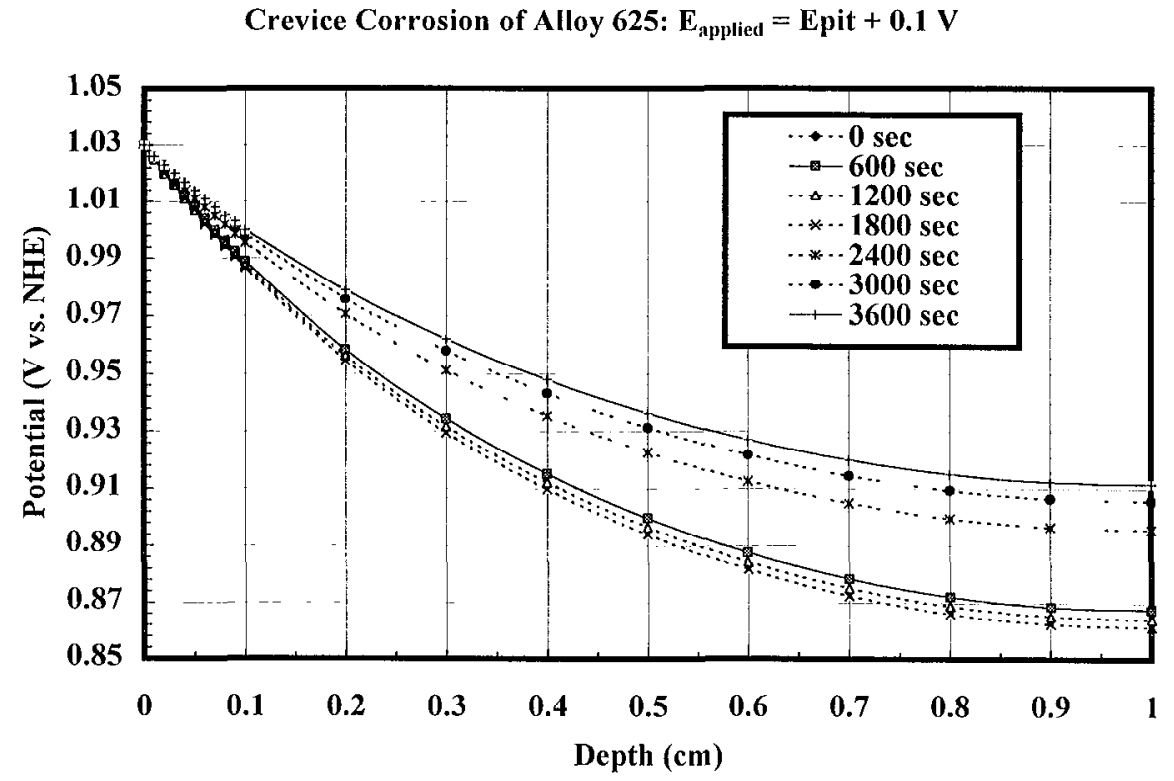

Figure 2. Electrochemical potential inside crevice is less severe than that applied in the mouth

In summary, the environmental conditions determined to be of greatest interest by consensus of the entire Expert Elicitation Panel are summarized below:

A. Temperature: $\mathrm{T}=25,50$, and $100^{\circ} \mathrm{C}$

B. Acidity: $\mathrm{pH}=2.5 \& 3-10$

C. Electrochemical Potential: $E=340 \& 640 \mathrm{mV}$ vs. SHE

\section{PASSIVE CORROSION RATES OF ALLOY C-22 IN RELEVANT ENVIRONMENTS}

\section{Questions:}

1) What is the general corrosion (or passive dissolution) rate of the $\mathrm{C}-22$ inner barrier in humid-air conditions (i.e., without drips) at 25,50 and $100^{\circ} \mathrm{C}$ ?

It is assumed that without drips, the inner barrier is exposed to mostly benign conditions in the potential repository.

The corrosion rates given should specify, as a minimum, the 0th and 100th percentile values along with the median, 5th percentile and 95 th percentile values

2) What is the general corrosion (or passive dissolution) rate of the inner barrier under dripping conditions?

Please consider the combination of temperature, $\mathrm{pH} 7-10$, and concentrated chemistry conditions represented by $1000 \mathrm{X} \mathrm{J}-13$ and fully saturated $\mathrm{J}-13$ : 
Draft Rev. 5 - J. C. Farmer, LLNL, YMP WP Degradation, Expert Elicitation Panel, Feb. 26, 1998

The corrosion rates given should specify, as a minimum, the 0th and 100th percentile values along with the median, 5th percentile and 95th percentile values.

\section{Response:}

Reasonable values for the penetration rate of Alloy C-22 due to dissolution through the passive film appear to be between 0.009 microns per year in a simulated, acidified, concentrated, J-13 well water, and 13 microns per year in a simulated crevice solution. Passive corrosion is consistent with opinions voiced by representative of the NRC. They state that no significant localized corrosion (localized penetration of the passive film) occurs at potentials well below the repassivation potential, $\mathrm{F}_{\text {pass. }}$. In the absence of radiolysis, the measured corrosion potential (mixed potential), $\mathrm{E}_{\text {corr }}$, in such environments appears to be well below $\mathrm{E}_{\text {pass. }}$. This is a general view held by other investigators in the ficld of corrosion science. The observed penetration rates for Alloy $\mathrm{C}-22$ in relevant environments are summarized in Figure 3, and are indicative of passive corrosion.

Range of Observed Penetration Rates for Alloy C-22

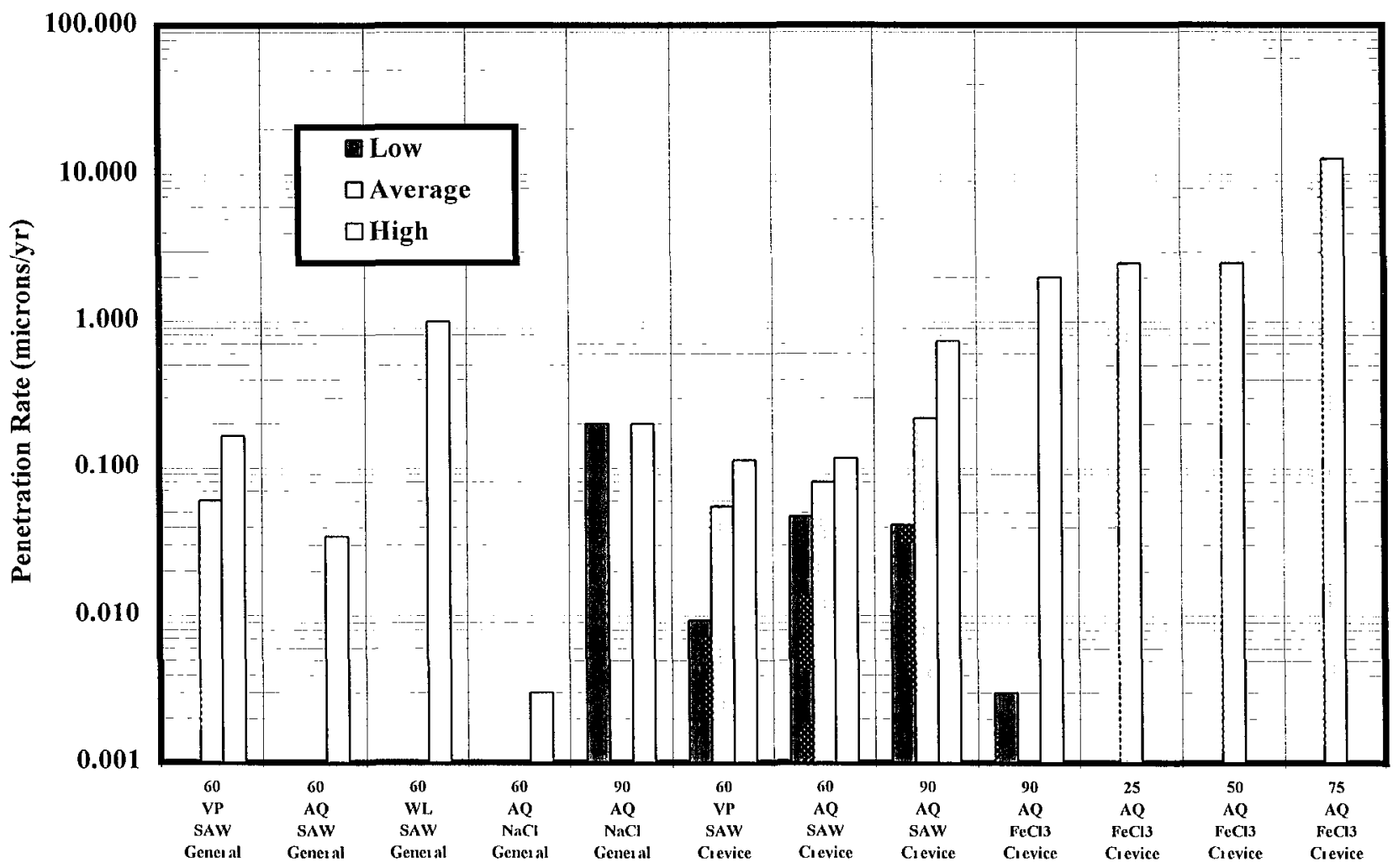

Figure 3. Observed Passive Corrosion Rates for Alloy C-22: Measured Weight Loss of Samples Exposed in Long Term Corrosion Test Facility (LTCTF); Corrosion Current Measurements at Open Circuit Potential (Roy, LLNL); and Measured Weight Loss of Samples Exposed to Simulated Crevice Solutions (Asphahani, Hanes International)

These observations are well represented by the regression equation (correlation) given to the EEP earlier. Data from the LTCTF was combined with the rates calculated from Roy's linear sweep polarization measurements, as well as the rates published by Asphahani. The combined data set was then used as the basis of an overall correlation of penetration rates with temperature, $\mathrm{pH}$, equivalent $\mathrm{NaCl}$ concentration, and $\mathrm{FeCl}_{3}$ [J. C. Farmer et al., "Development of Models for High-Level Waste Containers," Proc. $6^{\text {th }}$ Intl. Conf. On Nuclear Engineering, ICONE-6, May 10-15, 1998, San Diego, 
Draft Rev. 5 - J. C Farmer, III.NL, YMP WP Degradation, Expert Elicitation Panel, Feb. 26, 1998

California, ASME, 1998, 13 p.]. The following linear equation was found to be adequate for the correlation of Alloy C-22 penetration rates:

$\ln \left(\frac{\Delta p}{\Delta t}\right)=b_{0}+b_{1}\left(\begin{array}{c}1000 \\ T+273\end{array}\right)+b_{2}(p H)+b_{3}\left(C_{N a C l}\right)+b_{4}\left(C_{t e c / 3}\right)$

where $\Delta \mathrm{p} / \Delta \mathrm{t}$ is the apparent penetration rate $\left(\mu \mathrm{m} \mathrm{y}^{-1}\right) ; \mathrm{T}$ is the temperature $\left({ }^{\circ} \mathrm{C}\right) ; \mathrm{C}_{\mathrm{NaCl}}$ is the equivalent concentration of $\mathrm{NaCl}$ (wt. \%); and $\mathrm{C}_{\mathrm{FeCl} 3}$ is the concentration of $\mathrm{FeCl}_{3}$ (wt. \%). Within the bounds of thirty-eight (38) experimental observations for Alloy C-22, the coefficients were determined to be:

$b_{0}=+13.409$

$b_{1}=-5.5587$

$b_{2}=-0.87409$

$b_{3}=+0.56965$

$b_{4}=+0.60801$

More specifically, the correlation for Alloy C-22 is:

$\ln \left(\frac{\Delta p}{\Delta t}\right)=13.409-\left(\frac{5558.7}{T+273}\right)-0.87409(p H)+0.56965\left(C_{\mathrm{NaCl}^{\prime} \mathrm{l}}\right)+0.60801\left(C_{\mathrm{FeCl}_{3}}\right)$

The "standard error of estimate" ( $\mathrm{s}_{\mathrm{y} / 1234)}$ and the "sample multiple variable regression coefficient" $\left(\mathrm{r}_{\mathrm{y} / 1234}\right)$ are defined by Crow, Davis and Maxfield [E. L. Crow, F. A. Davis, M. W. Maxfield, Statistics Manual, Dover Publications, Inc., New York, NY, 1960, pp. 147-19]. The "standard error of estimate" is a measure of the scatter of the observed penetration rates about the regression plane. About $95 \%$ of the points in a large sample are expected to lie within $\pm 2 \mathrm{~s}_{\mathrm{y} / 123 \mathrm{k}}$ of the plane, measured in the $y$ direction. Values for the above correlation are:

$s_{y / 1234}=1.5092$

$r_{y / 1234}=0.65628$

The "multiple variable regression coefficient" indicates a reasonably good fit to the data set, given the large number of independent variables. As discussed in the literature, uncertainty in a given model parameter, $\beta_{\mathrm{j}}$, can be determined from the standard error of estimate, as shown by Eqns. 7 and 8 [E. L. Crow, F. A. Davis, M. W. Maxfield, Statistics Manual, Dover Publications, Inc., New York, NY, 1960, pp. 147-19]:

$s_{b_{j}}=s_{y / 123 k} \sqrt{n e_{i j}}$

$\beta_{i}=b_{j} \pm\left(t_{a / 2, n-k-1}\right) \times s_{b_{i}}$

This simple correlation has been tested within the bounds of anticipated conditions. The predictions appear to be reasonable for combinations of input parameters representative of the: Near Field Environment (NFE); SDW; SCW; SAW; SCMW; the unusually harsh, simulated crevice corrosion test 
of Asphahani (10 wt. \% $\mathrm{FeCl}_{3}$ ); and the conditions predicted during preliminary tests of the LLNL crevice transport model [J. C. Farmer, R. D. McCright, "Crevice Corrosion and Pitting of High-Level Waste Containers: Integration of Deterministic and Probabilistic Models," Paper No. 160, Annual Meeting of the National Association of Corrosion Engineers (NACE), Corrosion 98, San Diego, CA March 22-27, 1998]. The worst case within the bounds of the regression analysis is the simulated crevice condition used by Asphahani $\left(10 \mathrm{wt}\right.$. $\% \mathrm{FeCl}_{3}$ ). In the repository, the concentration of $\mathrm{FeCl}_{3}$ is expected to be limited to much lower values by the presence of carbonate, which precipitates iron. It must be noted that combinations of input parameters that are clearly beyond the range of the data included in the correlation cannot be used to generate reasonable predictions. Therefore, this correlation should not be used for saturated solutions of $\mathrm{J}-13$ and/or $\mathrm{FeCl}_{3}$. With in the limits of the experimental data, predictions are believed to be good representations of the observations.

For completeness, the above correlation also included observations of passive corrosion rate inferred from Ajit Roy's cyclic polarization measurements. It is well known that the corrosion (or penetration) rate of an alloy, $\mathrm{dp} / \mathrm{dt}$, can also be calculated from the corrosion current density, $\mathrm{i}_{\text {con }}$, as follows:

$$
\frac{d p}{d t}=\frac{i_{\text {corr }}}{\rho_{\text {allov }} n_{\text {alloy }} F}
$$

where $\rho_{\text {alloy }}$ is the density of the alloy, assumed to be approximately $8.4 \mathrm{~g} \mathrm{~cm}^{-3}$, and $\mathrm{F}$ is Faraday's constant. The number of gram equivalents per gram of alloy, $n_{\text {alloy }}$, is calculated with the following equation:

$n_{\text {allov }}=\sum_{i}\left(\frac{f_{j} n_{j}}{a_{i}}\right)$

where $f_{j}$ is the mass fraction of the $j$-th alloying element in the material, $n_{j}$ are the number of electrons involved in the anodic dissolution process, which is assumed to be congruent, and $a_{j}$ is the atomic weight of the $\mathrm{j}$-th alloying element. These equations have been used to calculate penetration rates for Alloy C-22 from apparent corrosion currents determined during cyclic polarization measurements. In principle, such electrochemically-determined rates should be consistent with those observed in the LTCTF, though experience indicates that such electrochemically-determined rates are conservative (higher than those actually observed).

The magnitude of the observed rates shown in Figure 3 appear to be consistent with those quoted in the article by Smailos, Schwarzkopf, and Koster [E. Smailos, W. Schwarzkopf, R. Koster, "Corrosion Behaviour of Container Materials for the Disposal of High-Level Wastes in Rock Salt Formations," Nuclear Science and Technology, Commission of the European Communities, DUR 10400, 1986], though the correlation cannot be used at such high salt concentration since data from experiments with saturated solutions were not included in the correlation. Penetration rates for Alloy $\mathrm{C}-4$ in a concentrated brine at 90,170 and $200^{\circ} \mathrm{C}$ are given. The authors state: "Hastelloy $\mathrm{C}-4$ has also resisted pitting corrosion and stress corrosion cracking, in the absence of irradiation, and its corrosion rate has been low at all testing temperatures ( $<1$ microns/yr), but it has becn attacked by crevice corrosion." The authors go on to state that when it is exposed to gamma irradiation at $\sim 10^{5} \mathrm{rad} / \mathrm{hr}$, pitting corrosion was observed. This pitting corrosion is believed by several investigators in the field to be due to the formation of oxidants such as $\mathrm{H}_{2} \mathrm{O}_{2}$, which shift the corrosion potential in the anodic direction, closer 
Draft Rev. 5 - J. C. Farmer, LLNL, YMP WP Degradation, Expert Elicitation Panel, Feb. 26, 1998

to the pitting and repassivation potential. At LLNL in the mid 1980's, Glass performed definitive radiolysis experiments showing that the corrosion potential of $316 \mathrm{~L}$ stainless steel in $0.018 \mathrm{M} \mathrm{NaCl}$ at $30^{\circ} \mathrm{C}$ shifted from approximately $-100 \mathrm{mV}$ vs. SCE to approximately $+100 \mathrm{mV}$ vs. SCE when exposed to gamma irradiation $\left(3.3 \times 10^{6} \mathrm{rad} / \mathrm{hr}\right)$ from a Co-60 source [R. S. Glass et al., Gamma Radiation Effects on Corrosion: I. Electrochemical Mechanisms for the Aqueous Corrosion Processes of Austenitic Stainless Steels Relevant to Nuclear Waste Disposal in Tuff, Corrosion Science, Vol. 26, No. 8, 1986, p. 577-590; J. C. Farmer et al., "Corrosion Models for Performance Assessment of HighLevel Radioactive-Waste Containers," Nuclear Engineering \& Design, Vol. 129, 1991, pp. 57-88]. The level of radiation expected at the outer surface of the CRM at the instant of CAM penetration is estimated to be orders-of-magnitude less than these exposures $\left(10^{5}-10^{6} \mathrm{rad} / \mathrm{hr}\right)$. At the Appendix 7 Meeting held at LLNL in February, 1998, the NRC said that they are ignoring the effects of radiolysis on corrosion, and believe that they are well justified in doing so. Note that radiolysis could form other oxidants, such as chlorine free radicals, ozone, and perhaps even unanticipated species such as peroxydisulfate, which has a very anodic redox potential. However, at low levels of radiation, the effects are not expected to be great. In regard to the $\mathrm{C}-4$ penetration rate data, it must be noted that at high temperature, the expected rates for $\mathrm{C}-22$ would be expected to be lower, as shown in Table 4 . In regard to this table, two rates attact particular attention: Alloy $\mathrm{C}, 5 \mathrm{wt} . \% \mathrm{FeCl}_{3}, 50^{\circ} \mathrm{C}, 0.075 \mathrm{~mm}$ crevice; Alloy $\mathrm{C}-276, \mathrm{H}_{2} \mathrm{SO}_{4} / \mathrm{HCl} / \mathrm{FeCl}_{3} / \mathrm{CuCl}_{2}, 50^{\circ} \mathrm{C}$.

Table 4. Published Penetration Rates (microns/yr) for Similar Alloys

\begin{tabular}{|c|c|c|c|c|c|c|}
\hline Exposure & $\mathrm{T}\left({ }^{\circ} \mathrm{C}\right)$ & $\mathrm{C}$ & $\mathrm{C}-4$ & $\mathrm{C}-276$ & $\mathrm{C}-22$ & Source \\
\hline 10 wt. $\% \mathrm{FeCl}_{3}$ & 25 & & 7.6 & 5.1 & 2.5 & Haynes, 1987 \\
\hline 10 wt. $\% \mathrm{FeCl}_{3}$ & 50 & & 12.7 & 2.5 & 2.5 & Haynes, 1987 \\
\hline 10 wt. $\% \mathrm{FeCl}_{3}$ & 75 & & 508 & 12.7 & 12.7 & Haynes, 1987 \\
\hline 5 wt. $\% \mathrm{FeCl}_{3}$ & 50 & 20 & & & & Jackson \& van Rooyen, 1972 \\
\hline 5 wt. $\% \mathrm{CuCl}_{2}$ & 50 & 10 & & & & Jackson \& van Rooyen, 1972 \\
\hline 5 wt. $\% \mathrm{NaOCl}$ & 50 & 6 & & & & Jackson \& van Rooyen, 1972 \\
\hline 5 wt. $\% \mathrm{FeCl}_{3}+5$ wt. $\% \mathrm{HCl}$ & 25 & 20 & & & & Jackson \& van Rooyen, 1972 \\
\hline 5 wt. $\% \mathrm{FeCl}_{3} * * *$ & 50 & 5200 & & & & Jackson \& van Rooyen, 1972 \\
\hline 10 wt. $\% \mathrm{FeCl}_{3}$ & 25 & & & 5.08 & & Asphahani, 1980 \\
\hline 10 wt. $\% \mathrm{FeCl}_{3}$ & 50 & & & 5.08 & & Asphahani, 1980 \\
\hline Sea Water, Surface** & 25 & & & Nil & & Hack, 1983 \\
\hline Sea Water, $2370-6780 \mathrm{ft}^{* *}$ & & & & Nil & & Reinhart, 1969 ( 24 samples) \\
\hline $\begin{array}{l}7 \text { vol. } \% \mathrm{H}_{2} \mathrm{SO}_{4}+ \\
3 \text { vol. } \% \mathrm{HCl}^{+} \\
1 \text { wt. } \% \mathrm{FeCl}_{3}+ \\
1 \text { wt. } \% \mathrm{CuCl}_{2}\end{array}$ & 25 & & & 7.62 & & Asphahani, 1980 \\
\hline $\begin{array}{l}7 \text { vol. } \% \mathrm{H}_{2} \mathrm{SO}_{4}+ \\
3 \text { vol. } \% \mathrm{HCl}+ \\
1 \text { wt. } \% \mathrm{FeCl}_{3}+ \\
1 \text { wt. } \% \mathrm{CuCl}_{2}\end{array}$ & 50 & & & 610 & & Asphahani, 1980 \\
\hline
\end{tabular}

Such high rates have not been observed with Alloy C-22 samples, configured in tight crevice geometries, and exposed to acidified ( $\mathrm{pH} 2.7)$, concentrated $(1000 \mathrm{X}) \mathrm{J}-13$ well water at $90^{\circ} \mathrm{C}$. In cases where such high rates have been observed with lesser alloys such as $\mathrm{C}-4$, the observed penetration rates for $\mathrm{C}-22$ have remained low [Haynes, 1987, $10 \mathrm{wt}$. $\% \mathrm{FeCl}_{3}$ ]. This raises three important questions: (a) can the NRC repassivation potential criteria be applied to Alloys C, C-4 and 
C-276 in cases where large penetration rates are predicted; (b) are measured penetration rates for Alloys C, C-4, and C-276 in mixed strong acids really indicative of the rates expected for C-22 in relevant repository environments; (c) are the $\mathrm{FeCl}_{3}$ environments reasonable simulations of a crevice; and (d) is the gradient in electric potential, or electric field, sufficient to induce complete separation of alkali metal cations and halide/oxy anions, thereby producing such an environment.? In regard to the last question, predictions based upon electic double layer theory indicate that electric fields of $10^{9}$ $\mathrm{V} / \mathrm{cm}$ at the electrode-electrolyte interface (across the compact double layer) may be possible. The field in the diffuse double layer is much less. The extreme field strengths in the compact double layer are believed to be sufficient to induce complete charge separation. However, since such gradients do not exist in the bulk electrolyte found in crevices, pits and cracks, what physical process could be responsible for creating concentrated mixtures of $\mathrm{H}_{2} \mathrm{SO}_{4}$ and $\mathrm{HCl}$ ? What plausible scenario can we provide to create environments where such high penetration rats have been observed?

Values for $1000 \mathrm{X} \mathrm{J}-13$ are based upon the above correlation, since the chloride concentration is within the range of data included in the correlation [J. C. Farmer et al., "Development of Corrosion Models for High-Level Waste Containers," Proc. $6^{\text {th }}$ International Conference on Nuclear Engineering, ICONE-6, San Diego, CA, May 10-15, 1998, ASME, 1998, 13 p.]. In the case of saturated J-13, estimates are based upon the article by Smailos, Schwarzkopf, and Koster [E. Smailos, W. Schwarzkopf, R. Koster, "Corrosion Behaviour of Container Materials for the Disposal of High-Level Wastes in Rock Salt Formations," Nuclear Science and Technology, Commission of the European Communities, DUR 10400, 1986], as interpreted by another member of the Expert Elicitation Panel [D. Shoesmith, "Passive Corrosion of the CRM," electronic mail message, February 13, 1998]. The data quoted by Shoesmith is for "Q-Brine" and "Z-Brine" electrolytes, as shown Table 5a.

Table 5a. Data for Passive Corrosion in Saturated Brines (Smailos et al.; Shoesmith).

\begin{tabular}{|c|c|c|c|c|c|c|c|c|c|}
\hline Brine & $\mathrm{pH}$ & $\mathrm{NaCl}$ & $\mathrm{KCl}$ & $\mathrm{MgCl}_{2}$ & $\mathrm{MgSO}_{4}$ & $\mathrm{H}_{2} \mathrm{O}$ & $90^{\circ} \mathrm{C}$ Rate & $170^{\circ} \mathrm{C}$ Rate & $\mathrm{pH}$ \\
\hline & & wt. \% & wt. \% & wt. \% & wt. \% & wt. \% & $\mu \mathrm{m} / \mathrm{yr}$ & $\mu \mathrm{m} / \mathrm{yr}$ & Shoesmith \\
\hline $\mathrm{Q}$ & 4.9 & 1.4 & 4.7 & 26.8 & 1.4 & 65.7 & 0.02 & $0.15-0.66$ & $\sim 5$ \\
\hline $\mathrm{Z}$ & 3.6 & 0.2 & 0.66 & 36.4 & 0.87 & 61.9 & $10-14$ & & $\sim 2$ \\
\hline
\end{tabular}

The rate of $10-14$ microns/yr in Z-Brine at $90^{\circ} \mathrm{C}$ is interpreted as the "maximum possible" value by Shoesmith (taken here as rate at $99^{\text {th }}$ percentile). According to page 10 of the Smailos Report: "After three years of exposure until now Hastelloy C-4 has remained resistant to pitting corrosion, and to stress corrosion cracking. At $90^{\circ} \mathrm{C}$ local crevice corrosion attacks occurred at single points at the metal/PTFE and metal/metal contact surfaces with maxiumum depths of 250 microns (metal/PTFE), and 20-70 microns (metal/metal), respectively." This translates into a maximum penetration rate of 15-51 microns/yr. It must be noted that the rates from the Smailos et al. Report had to be scaled for $\mathrm{pH}$ and temperature so that all conditions of interest in this elicitation could be covered. While the base rate used was taken from the "Z-Brine" data, the activation energy used to scale the rate for temperature had to be inferred from the "Q-Brine" data. A very reasonable value of the activation energy, $E_{a}$, was estimated to be approximately $12 \mathrm{kcal} / \mathrm{mol}$. The estimate was made with the following equation, which is based upon an Ahrenius-type rate expression:

$$
\frac{r_{1}}{r_{2}}=\exp \left[\frac{E_{a}}{R}\left(\frac{1}{T_{2}}-\frac{1}{T_{1}}\right)\right]
$$


At $170^{\circ} \mathrm{C}\left(\mathrm{T}_{1}\right)$, the observed penetration rates were given as 0.66 amnd $0.15 \mathrm{microns} / \mathrm{yr}$, which were averaged to give a single value of 0.4 microns $/ y r\left(\mathrm{r}_{1}\right)$. At a lower temperature of $90^{\circ} \mathrm{C}\left(\mathrm{T}_{2}\right)$, the observed rate was given as 0.02 microns/yr $\left(\mathrm{r}_{2}\right)$. Rates were scaled with the $\mathrm{pH}$ as implied by the correlation, since no better means of estimating the response is available. Therefore, the rates were assumed to obey the following empirical law:

$$
\frac{r_{1}}{r_{2}}=\exp \left[0.87409\left(\mathrm{pH}_{2}-p H_{1}\right)\right]
$$

Establishment of CDF's for 1000X and saturated J-13 cases require estimation distribution width about the mean. In regard to estimates based upon either the correlation and Shoesmith's interpretation of data published by Smailos et al., it was assumed that logarithimic rates were distributed normally about the mean logarithmic rate. To determine the CDF's for $1000 \mathrm{X} \mathrm{J}-13$, which was based upon the correlation, the following simplifying approximations were made:

$$
\begin{aligned}
& y=\ln \left[\frac{\Delta p}{\Delta t}\right] \\
& y_{5 \%} \approx y_{\text {predicted }}-\delta y_{\alpha=0.05} \approx y_{\text {preditited }}-t_{\alpha=005} s_{173 k} \\
& y_{95 \%} \approx y_{\text {predicted }}+\delta y_{\alpha=0 \text { 05 }} \approx y_{\text {preticted }}+l_{\alpha=0 \text { 05 }} s_{y / 123 k} \\
& t_{\alpha=0 \text { 05 }} \approx 1.70 \\
& y_{1 \%} \approx y_{\text {predicted }}-\delta y_{\alpha=0 \text { 01 }} \approx y_{\text {predicted }}-t_{\alpha=0 \text { 01 }} s_{y / 123 k} \\
& y_{99 \%} \approx y_{\text {predicted }}+\delta y_{\alpha=0,01} \approx y_{\text {predicted }}+t_{\alpha=0 \text { 01 }} s_{y / 123 k} \\
& t_{\alpha=001} \approx 2.46 \\
& r_{5 \%}=\left[\frac{\Delta p}{\Delta t}\right]_{5 \%} \approx \exp \left[y_{\text {predicted }}-1.70 \times s_{y / 123 k}\right] \\
& r_{95 \%}=\left[\frac{\Delta p}{\Delta t}\right]_{95 \%} \approx \exp \left[y_{\text {predicted }}+1.70 \times s_{\nu / 123} k\right] \\
& r_{1 \%}=\left[\frac{\Delta p}{\Delta t}\right]_{1 \%} \approx \exp \left[y_{\text {predicted }}-2.46 \times s_{y / 123} k\right] \\
& r_{99 \%}=\left[\frac{\Delta p}{\Delta t}\right]_{99 \%} \approx \exp \left[y_{\text {predicted }}+2.46 \times s_{v / 123} k\right]
\end{aligned}
$$


Draft Rev. 5 - J. C. Farmer, IIINI, YMP WP Degradation, Expert Elicitation Panel, Feb. 26, 1998

The CDF's based upon Smailos et al. assumed values at the $99^{\text {th }}$ and $50^{\text {th }}$ percentiles, and then assumed a log-normal distribution to estimate values at other percentiles. In this case, the standard deviation was estimated to be about 1.6228 , the value of $u_{\alpha=0}$ was assumed to be 1.645 and the value of $u_{\alpha=0} 01$ was assumed to be 2.326. Based on the foregoing considerations, this member of the Expert Elicitation Panel proposes estimates for passive corrosion rates of the CRM represented by the CDF's summarized in Table 5b. Bold-face values correspond to rates taken from Table $5 \mathrm{a}$.

Table $5 b$ Estimates of the CDF for Passive Penetration Rates-Dripping

\begin{tabular}{|c|c|c|c|c|c|c|c|c|}
\hline Data Source & & $\begin{array}{c}\text { Regression } \\
\text { (Farmer) }\end{array}$ & $\begin{array}{c}\text { Regression } \\
\text { (Farmer) }\end{array}$ & $\begin{array}{c}\text { Regression } \\
\text { (Farmer) }\end{array}$ & $\begin{array}{c}\text { Smailos } \\
\text { (Shoesmith) }\end{array}$ & $\begin{array}{c}\text { Smailos } \\
\text { (Shoesmith) }\end{array}$ & $\begin{array}{c}\text { Smailos } \\
\text { (Shoesmith) }\end{array}$ & $\begin{array}{c}\text { Smailos } \\
\text { (Shoesmith) }\end{array}$ \\
\hline Environment & & $1000 \times \mathrm{J}-13$ & $1000 \mathrm{X} J-13$ & $1000 \mathrm{X} \mathrm{J}-13$ & Z-Brine & Z-Brine & Z-Brine & Z-Brine \\
\hline $\mathrm{NaCl}($ wt. \%) & & 1.2 & 1.2 & 1.2 & Saturated & Saturated & Saturated & Saturated \\
\hline $\mathrm{T}\left({ }^{\circ} \mathrm{C}\right)$ & & 25 & 50 & 100 & 90 & 25 & 50 & 100 \\
\hline Percentile (\%) & $\mathrm{pH}$ & microns/yr & microns/yr & microns/yr & microns/yr & microns/yr & microns/yr & microns/yr \\
\hline 50 & 1 & $4.36 \times 10^{-3}$ & $1.85 \times 10^{-2}$ & $1.86 \times 10^{-1}$ & $6.60 \times 10^{-1}$ & $1.71 \times 10^{-2}$ & $8.29 \times 10^{-2}$ & 1.03 \\
\hline 50 & 2 & $1.82 \times 10^{-3}$ & $7.71 \times 10^{-3}$ & $7.74 \times 10^{-2}$ & $2.75 \times 10^{-1}$ & $7.13 \times 10^{-3}$ & $3.46 \times 10^{-2}$ & $4.31 \times 10^{-1}$ \\
\hline 50 & 3 & $7.59 \times 10^{-4}$ & $3.22 \times 10^{-3}$ & $3.23 \times 10^{-2}$ & $1.15 \times 10^{-1}$ & $2.98 \times 10^{-3}$ & $1.44 \times 10^{-2}$ & $1.80 \times 10^{-1}$ \\
\hline 50 & 5 & $1.32 \times 10^{-4}$ & $5.60 \times 10^{-4}$ & $5.62 \times 10^{-3}$ & $2.00 \times 10^{-2}$ & $5.18 \times 10^{-4}$ & $2.51 \times 10^{-3}$ & $3.13 \times 10^{-2}$ \\
\hline 50 & 7 & $2.30 \times 10^{-5}$ & $9.75 \times 10^{-5}$ & $9.79 \times 10^{-4}$ & $3.48 \times 10^{-3}$ & $9.02 \times 10^{-5}$ & $4.38 \times 10^{-4}$ & $5.46 \times 10^{-3}$ \\
\hline 50 & 10 & $1.67 \times 10^{-6}$ & $7.08 \times 10^{-6}$ & $7.11 \times 10^{-5}$ & $2.53 \times 10^{-4}$ & $6.55 \times 10^{-6}$ & $3.18 \times 10^{-5}$ & $3.96 \times 10^{-4}$ \\
\hline Percentile & $\mathrm{pH}$ & microns/yr & microns/yr & microns/yr & microns/yr & microns/yr & microns/yr & microns/yr \\
\hline 5 & 1 & $3.35 \times 10^{-4}$ & $1.42 \times 10^{-3}$ & $1.43 \times 10^{-2}$ & $4.57 \times 10^{-2}$ & $1.18 \times 10^{-3}$ & $5.75 \times 10^{-3}$ & $7.16 \times 10^{-2}$ \\
\hline 5 & 2 & $1.40 \times 10^{-4}$ & $5.93 \times 10^{-4}$ & $5.95 \times 10^{-3}$ & $1.91 \times 10^{-2}$ & $4.94 \times 10^{-4}$ & $2.40 \times 10^{-3}$ & $2.99 \times 10^{-2}$ \\
\hline 5 & 3 & $5.84 \times 10^{-5}$ & $2.47 \times 10^{-4}$ & $2.48 \times 10^{-3}$ & $7.96 \times 10^{-3}$ & $2.06 \times 10^{-4}$ & $1.00 \times 10^{-3}$ & $1.25 \times 10^{-2}$ \\
\hline 5 & 5 & $1.02 \times 10^{-5}$ & $4.31 \times 10^{-5}$ & $4.32 \times 10^{-4}$ & $1.39 \times 10^{-3}$ & $3.59 \times 10^{-5}$ & $1.74 \times 10^{-4}$ & $2.17 \times 10^{-3}$ \\
\hline 5 & 7 & $1.77 \times 10^{-6}$ & $7.49 \times 10^{-6}$ & $7.53 \times 10^{-5}$ & $2.41 \times 10^{-4}$ & $6.25 \times 10^{-6}$ & $3.03 \times 10^{-5}$ & $3.78 \times 10^{-4}$ \\
\hline 5 & 10 & $1.29 \times 10^{-7}$ & $5.44 \times 10^{-7}$ & $5.47 \times 10^{-6}$ & $1.75 \times 10^{-5}$ & $4.54 \times 10^{-7}$ & $2.20 \times 10^{-6}$ & $2.75 \times 10^{-5}$ \\
\hline Percentile & $\mathrm{pH}$ & microns/yr & microns/yr & microns/yr & microns/yr & microns/yr & microns/yr & microns/yr \\
\hline 95 & 1 & $5.67 \times 10^{-2}$ & $2.40 \times 10^{-1}$ & 2.41 & 9.52 & $2.47 \times 10^{-1}$ & 1.20 & 14.9 \\
\hline 95 & 2 & $2.37 \times 10^{-2}$ & $1.00 \times 10^{-1}$ & 1.01 & 3.97 & $1.03 \times 10^{-1}$ & $4.99 \times 10^{-1}$ & 6.23 \\
\hline 95 & 3 & $9.88 \times 10^{-3}$ & $4.19 \times 10^{-2}$ & $4.20 \times 10^{-1}$ & 1.66 & $4.30 \times 10^{-2}$ & $2.08 \times 10^{-1}$ & 2.60 \\
\hline 95 & 5 & $1.72 \times 10^{-3}$ & $7.29 \times 10^{-3}$ & $7.32 \times 10^{-2}$ & $2.89 \times 10^{-1}$ & $7.48 \times 10^{-3}$ & $3.63 \times 10^{-2}$ & $4.52 \times 10^{-1}$ \\
\hline 95 & 7 & $2.99 \times 10^{-4}$ & $1.27 \times 10^{-3}$ & $1.27 \times 10^{-2}$ & $5.03 \times 10^{-2}$ & $1.30 \times 10^{-3}$ & $6.31 \times 10^{-3}$ & $7.87 \times 10^{-2}$ \\
\hline 95 & 10 & $2.17 \times 10^{-5}$ & $9.21 \times 10^{-5}$ & $9.25 \times 10^{-4}$ & $3.65 \times 10^{-3}$ & $9.46 \times 10^{-5}$ & $4.59 \times 10^{-4}$ & $5.72 \times 10^{-3}$ \\
\hline Percentile & $\mathrm{pH}$ & microns/yr & microns/yr & microns/yr & microns/yr & microns/yr & microns/yr & microns/yr \\
\hline 1 & 1 & $1.06 \times 10^{-4}$ & $4.51 \times 10^{-4}$ & $4.53 \times 10^{-3}$ & $1.51 \times 10^{-2}$ & $3.92 \times 10^{-4}$ & $1.90 \times 10^{-3}$ & $2.37 \times 10^{-2}$ \\
\hline 1 & 2 & $4.44 \times 10^{-5}$ & $1.88 \times 10^{-4}$ & $1.89 \times 10^{-3}$ & $6.32 \times 10^{-3}$ & $1.64 \times 10^{-4}$ & $7.94 \times 10^{-4}$ & $9.90 \times 10^{-3}$ \\
\hline 1 & 3 & $1.85 \times 10^{-5}$ & $7.85 \times 10^{-5}$ & $7.89 \times 10^{-4}$ & $2.64 \times 10^{-3}$ & $6.83 \times 10^{-5}$ & $3.31 \times 10^{-4}$ & $4.13 \times 10^{-3}$ \\
\hline 1 & 5 & $3.23 \times 10^{-6}$ & $1.37 \times 10^{-5}$ & $1.37 \times 10^{-4}$ & $4.59 \times 10^{-4}$ & $1.19 \times 10^{-5}$ & $5.77 \times 10^{-5}$ & $7.19 \times 10^{-4}$ \\
\hline 1 & 7 & $5.62 \times 10^{-7}$ & $2.38 \times 10^{-6}$ & $2.39 \times 10^{-5}$ & $7.99 \times 10^{-5}$ & $2.07 \times 10^{-6}$ & $1.00 \times 10^{-5}$ & $1.25 \times 10^{-4}$ \\
\hline 1 & 10 & $4.08 \times 10^{-8}$ & $1.73 \times 10^{-1}$ & $1.74 \times 10^{-6}$ & $5.80 \times 10^{-6}$ & $1.50 \times 10^{-7}$ & $7.29 \times 10^{-1}$ & $9.09 \times 10^{-6}$ \\
\hline Percentile (\%) & $\mathrm{pH}$ & microns/yr & microns/yr & microns/yr & microns/yr & microns/yr & microns/yr & microns/yr \\
\hline 99 & 1 & $1.79 \times 10^{1}$ & $7.57 \times 10^{-1}$ & 7.60 & 28.8 & $7.45 \times 10^{-1}$ & 3.61 & 45.1 \\
\hline 99 & 2 & $7.45 \times 10^{-2}$ & $3.16 \times 10^{-1}$ & 3.17 & 12.0 & $3.11 \times 10^{-1}$ & 1.51 & 18.8 \\
\hline 99 & 3 & $3.11 \times 10^{-2}$ & $1.32 \times 10^{-1}$ & 1.32 & 5.01 & $1.30 \times 10^{-1}$ & $6.29 \times 10^{-1}$ & 7.84 \\
\hline 99 & 5 & $5.41 \times 10^{-3}$ & $2.29 \times 10^{-2}$ & $2.30 \times 10^{-1}$ & $8.72 \times 10^{-1}$ & $2.26 \times 10^{-2}$ & $1.10 \times 10^{-1}$ & 1.37 \\
\hline 99 & 7 & $9.43 \times 10^{-4}$ & $3.99 \times 10^{-3}$ & $4.01 \times 10^{-2}$ & $1.52 \times 10^{-1}$ & $3.93 \times 10^{-3}$ & $1.91 \times 10^{-2}$ & $2.38 \times 10^{-1}$ \\
\hline 99 & 10 & $6.85 \times 10^{-5}$ & $2.90 \times 10^{-4}$ & $2.91 \times 10^{-3}$ & $1.10 \times 10^{-2}$ & $2.86 \times 10^{-4}$ & $1.39 \times 10^{-3}$ & $1.73 \times 10^{-2}$ \\
\hline
\end{tabular}


Draft Rev 5 - J. C. Farmer, LLNL, YMP WP Degradation, Expert Elicitation Panel, Feb. 26, 1998

Estimates for humid air corrosion assume rates comparable to those for aqueous-phase passive corrosion at neutral $\mathrm{pH}$, which appears to be more or less consistent with the impressive "mirror finish" of an Alloy C sample after 56 years exposure to a coastal environment on the coast of North Carolina (Table 5c).

Table 5c. Estimates of the CDF for Passive Penetration Rates - Humid Air Corrosion.

\begin{tabular}{|c|c|c|c|}
\hline $\mathrm{T}\left({ }^{\circ} \mathrm{C}\right)$ & 25 & 50 & 100 \\
\hline Percentile (\%) & microns/yr & microns/yr & microns/yr \\
\hline 1 & $5.62 \times 10^{-7}$ & $2.38 \times 10^{-6}$ & $2.39 \times 10^{-5}$ \\
\hline 5 & $1.77 \times 10^{-6}$ & $7.49 \times 10^{-6}$ & $7.53 \times 10^{-5}$ \\
\hline 50 & $2.30 \times 10^{-5}$ & $9.75 \times 10^{-5}$ & $9.79 \times 10^{-4}$ \\
\hline 95 & $2.99 \times 10^{-4}$ & $1.27 \times 10^{-3}$ & $1.27 \times 10^{-2}$ \\
\hline 99 & $9.43 \times 10^{-4}$ & $3.99 \times 10^{-3}$ & $4.01 \times 10^{-2}$ \\
\hline
\end{tabular}

\section{PIT INITIATION PROBABILITY}

\section{Questions:}

3) What is the probability of initiating localized (crevice) corrosion of the inner barrier under the following conditions?

$\mathrm{T}=25^{\circ} \mathrm{C}$

1) $\mathrm{pH} 2.5$ and potential of $340 \mathrm{mV}_{\mathrm{SHE}}$ and $640 \mathrm{mV}_{\mathrm{SHE}}$

$\mathrm{T}=50^{\circ} \mathrm{C}$

2) $\mathrm{pH} \mathrm{3-10}$ and potential of $340 \mathrm{mV}_{\mathrm{SHE}}$

1) $\mathrm{pH} 2.5$ and potential of $340 \mathrm{mV}_{\mathrm{SHE}}$ and $640 \mathrm{mV}_{\mathrm{SHE}}$

2) $\mathrm{pH} \mathrm{3-10}$ and potential of $340 \mathrm{mV}_{\mathrm{SHE}}$

$\mathrm{T}=100^{\circ} \mathrm{C}$

1) $\mathrm{pH} 2.5$ and potential of $340 \mathrm{mV}_{\mathrm{SHE}}$ and $640 \mathrm{mV}_{\mathrm{SHE}}$

2) $\mathrm{pH} \mathrm{3-10}$ and potential of $340 \mathrm{mV}_{\mathrm{SHE}}$

\section{Response:}

The probability of localized corrosion, which is assumed to include both crevice corrosion and pit initiation, is based upon observations of the pitting and repassivation potential. First, all observed values are placed on a common potential scale, that of the standard hydrogen electrode (SHE). Correlations have been obtained for the electrochemical potentials of the $\mathrm{AgCl}$ and SCE reference electrodes as functions of temperature. The first correlation for $\mathrm{Ag} / \mathrm{AgCl} / 0.1 \mathrm{M} \mathrm{KCl}$ was provided by David Shoesmith and was developed by AECL [King et al., "A High-Temperature, High-Pressure, Silver-Silver Chloride Reference Electrode: A User's Guide," AECL-9890, 1989].

$$
E_{\text {AgCl }}(S H E)=0.23755-5.3783 \times 10^{-4} \mathrm{~T}\left({ }^{\circ} \mathrm{C}\right)-2.3728 \times 10^{-6} \mathrm{~T}\left({ }^{\circ} \mathrm{C}\right)^{2}+2.2671 \times 10^{-4}\left[\mathrm{~T}\left({ }^{\circ} \mathrm{C}\right)+273\right]
$$

The second correlation for $\mathrm{Hg} / \mathrm{Hg}_{2} \mathrm{Cl}_{2}$ satd. $\mathrm{KCl}$ was obtained from the well-known text by Bard \& Faulkner [A. J. Bard, L. R. Faulkner, Electrochemical Methods, Fundamentals and Applications, John Wiley \& Sons, New York, NY, 1980]. 
Draft Rev. 5-J. C. Farmer, LI.NI, YMP WP Degradation, Expert Elicitation Panel, Feb. 26, 1998

$E_{\text {SCE }}(S H E)-0.2412-6.61 \times 10^{-4}\left[T\left({ }^{\circ} \mathrm{C}\right)-25\right]-1.75 \times 10^{-6}\left[T\left({ }^{\circ} \mathrm{C}\right)-25\right]^{2}-9.0 \times 10^{-10}\left[T\left({ }^{\circ} \mathrm{C}\right)-25\right]^{3}$

Relevant temperature corrections can be calculated with each of these expressions, as given in Table 6 below:

Table 6. Correction of Reference Electrodes for Temperature Excursion from Ambient.

\begin{tabular}{|l|l|l|}
\hline $\mathrm{T}\left({ }^{\circ} \mathrm{C}\right)$ & $\mathrm{E}_{\mathrm{Ag} / \mathrm{AgCl} / 01 \mathrm{M} \mathrm{KCl}}$ (V vs. SHE) & $\mathrm{E}_{\mathrm{SCE}}$ (V vs. SHE) \\
\hline 25 & 0.2902 & 0.2412 \\
\hline 60 & 0.2722 & 0.2344 \\
\hline 90 & 0.2629 & 0.1906 \\
\hline 95 & 0.2485 & 0.1861 \\
\hline
\end{tabular}

In the case of the $\mathrm{Ag} / \mathrm{AgCl} / 0.1 \mathrm{M} \mathrm{KCl}$ electrode, the potential must also be corrected for electrolyte concentration, so that it is applicable for the standard $\mathrm{AgCl}$ electrode with saturated $\mathrm{KCl}$. First, the solubility of $\mathrm{KCl}$ as a function of temperature is obtained from the CRC Handbook [CRC Handbook, Chemical Rubber Company, $61^{\text {st }}$ Edition, 1980-81, p. B-132].

$T=20^{\circ} \mathrm{C}: \quad C_{\text {saturted } K C l}=23.8$ grams per $100 \mathrm{cc}$

$T=100^{\circ} \mathrm{C}: \quad C_{\text {salurated } K C^{\prime} \text { l }}=56.7$ grams per $100 \mathrm{cc}$

The saturation concentrations at other temperatures is estimated by simple linear interpolation, as shown in Table 7:

Table 7. Saturation Concentration of $\mathrm{KCl}$ by Linear Interpolation.

\begin{tabular}{|l|l|l|}
\hline $\mathrm{T}\left({ }^{\circ} \mathrm{C}\right)$ & $\mathrm{C}_{\text {saturated KCl }}(\mathrm{g}$ per $100 \mathrm{cc})$ & $\mathrm{C}_{\text {saturated KCl }}(\mathrm{mol} / \mathrm{kg})$ \\
\hline 20 & 23.8 & 3.192 \\
\hline 25 & 25.86 & 3.468 \\
\hline 60 & 40.25 & 5.398 \\
\hline 90 & 52.59 & 7.053 \\
\hline 95 & 54.64 & 7.329 \\
\hline 100 & 56.7 & 7.605 \\
\hline
\end{tabular}

Note that a formula weight of $\mathrm{KCl}$ is assumed to be approximately 74.56 , and ignores any hydration effects. Obviously, we have ignored activity coefficients. The Debye-Huckel equation could be used to esitmate the activity coefficients, however, it only applies rigorously to infinitely dilute solutions. Other activity coefficient models for higher electrolyte concentrations are controversial, due to a gencral lack of knowledge of the sphere of hydration surrounding individual ions, a general inability to account for Coulombic and dipole interactions between each pair of individual ions, and other equally important effects. A simplification of the Nernst equation, which also ignores activity coefficients, can be used to make a first order correction of the potential of the $\mathrm{Ag} / \mathrm{AgCl} / \mathrm{KCl}$ reference electrode for $\mathrm{KCl}$ concentration. The Nernst equation can be written as:

$$
E=E^{0}+\frac{R T}{n F^{\prime}} \ln \frac{C_{O}}{C_{R}}
$$

where the convention is assumed to be: 
Draft Rev 5 -.J C. Farmer, LLNL, YMP WP Degradation, Expert Elicitation Panel, Feb. 26, 1998

$O+n e^{-\stackrel{\text { electrode }}{\longrightarrow}} R$

Application of this simplified Nernst equation to the $\mathrm{Ag} / \mathrm{AgCl} / \mathrm{KCl}$ reference electrode yields:

$E_{A g / A g C l / \text { satd } K C l}-E_{A g / A g C l / 01 M K C l}=-\frac{R T}{F} \ln \frac{C_{\text {setd } / K C l}}{C_{0 I M K C l}}$

where the assumed reaction is:

$\mathrm{AgCl}+e^{-} \longrightarrow \mathrm{Ag}+\mathrm{Cl}^{-}$

Given Faraday's constant of $9.64846 \times 10^{4}$ C/equiv, the value of RT/F at $25^{\circ} \mathrm{C}$ is $0.02569 \mathrm{~V}$, and can be scaled to different temperatures (Table 8).

Table 8. Correction of Electrode Potenial for Concentration.

\begin{tabular}{|l|l|l|l|l|l|l|}
\hline $\mathrm{T}\left({ }^{\circ} \mathrm{C}\right)$ & $\mathrm{RT} / \mathrm{F}(\mathrm{V})$ & $\begin{array}{l}\mathrm{E}_{\text {Ag/AgCl/ 1 M KCl }} \\
\text { (V vS. SHE) }\end{array}$ & $\begin{array}{l}\mathrm{C}_{\text {saturated KCl }} \\
(\mathrm{mol} / \mathrm{kg})\end{array}$ & $\begin{array}{l}\text { Concentration } \\
\text { Correction (V) }\end{array}$ & $\begin{array}{l}\mathrm{E}_{\text {Ag/AgCl/satd KCl }} \\
\text { V vs. SHE) }\end{array}$ & $\begin{array}{l}\mathrm{E}_{\text {SCE }} \\
\text { (V vs. SHE) }\end{array}$ \\
\hline 25 & 0.02569 & 0.2902 & 3.468 & -0.0911 & 0.1991 & 0.2412 \\
\hline 60 & 0.02871 & 0.2722 & 5.398 & -0.1145 & 0.1577 & 0.2344 \\
\hline 90 & 0.03129 & 0.2629 & 7.053 & -0.1332 & 0.1297 & 0.1906 \\
\hline 95 & 0.03172 & 0.2485 & 7.329 & -0.1362 & 0.1123 & 0.1861 \\
\hline
\end{tabular}

Application of these corrections to measured corrosion, pitting, and repassivation potentials is summarized in Tables $9 \mathrm{a}$ and $9 \mathrm{~b}$. Note that the interpretation of cyclic polarization (CP) curves is very subjective. Where more than one inflection point might be interpreted as the potential of interest, the most conservative value was chosen (least anodic repassivation potential, for example). These data are summarized in Figure 4.

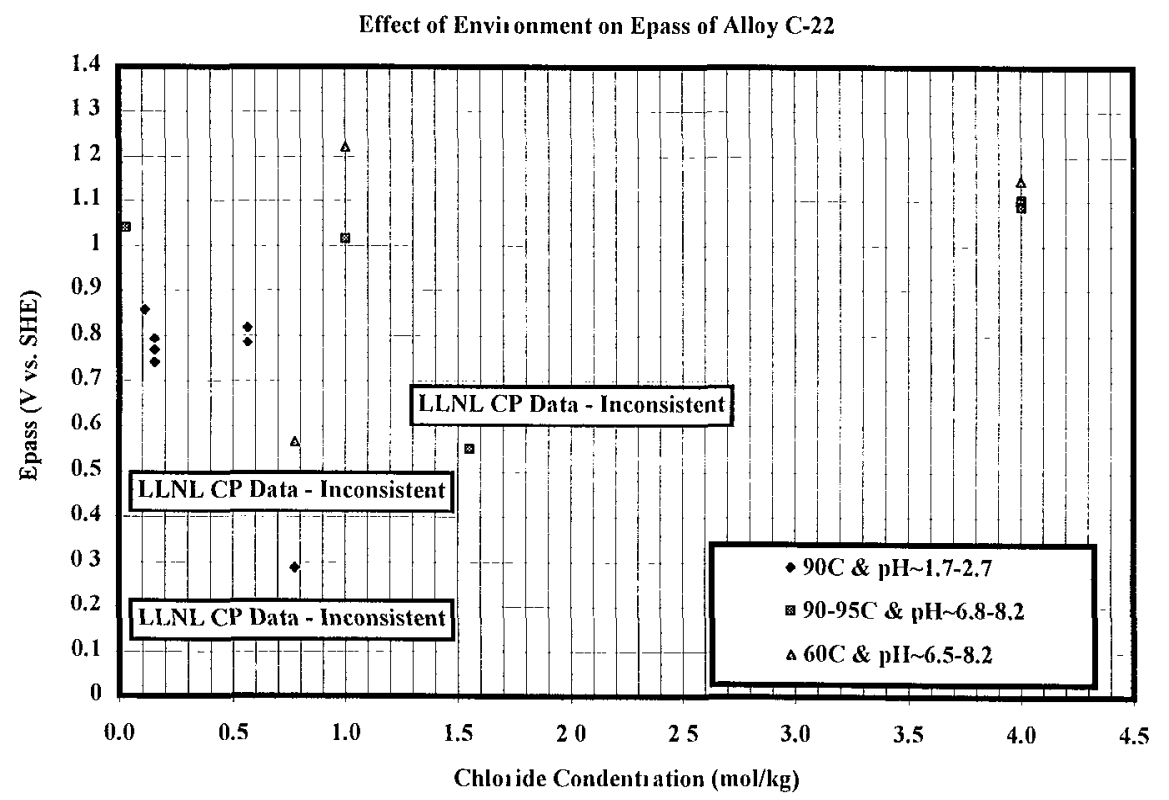

Figure 4. Observations of repassivation potential as a function of chloride concentration, temperature, and $p H$. 
Table 9a. Corrosion and Threshold Potentials (vS. SHE) Measured by LLNL \& NRC.

\begin{tabular}{|c|c|c|c|c|c|c|c|c|c|c|c|}
\hline Source & $\mathrm{ID}$ & $\mathrm{T}$ & $\mathrm{T}$ & $\mathrm{NaCl}$ & $\mathrm{FeCl}_{3}$ & $\mathrm{Cl}^{-}$ & $\mathrm{pH}$ & $\mathrm{E}_{\text {cot }}$ & $\mathrm{E}_{\text {pit }}$ low & $\mathrm{E}_{\text {pit }}$ - high & $\mathrm{E}_{\text {pass }}$ \\
\hline & & $\mathrm{C}$ & $\mathrm{K}$ & $\mathrm{Wt} . \%$ & $\mathrm{Wt} \%$ & $\mathrm{~mol} / \mathrm{kg}$ & & V vs. Ref. & V vs. Ref. & V vs. Ref. & V vs. Ref. \\
\hline LLNL & $090996 \mathrm{C} 1$ & 90 & 363 & 10.00 & 0 & 1.552 & 6.83 & -0.154 & 0.312 & 0.312 & 0.42 \\
\hline LLNL & $103397 \mathrm{Cl}$ & 90 & 363 & 1.00 & 0 & 0.155 & 2.69 & -0.159 & 0.628 & 0.733 & 0.663 \\
\hline LLNL & $102497 \mathrm{C} 2$ & 90 & 363 & 1.00 & 0 & 0.155 & 2.67 & -0.162 & 0.628 & 0.785 & 0.611 \\
\hline LLNL & $102797 \mathrm{C} 1$ & 90 & 363 & 5.00 & 0 & 0.776 & 2.69 & -0.202 & 0.423 & 0.654 & 0.158 \\
\hline LLNL & $081997 \mathrm{C} 1$ & 90 & 363 & 1.00 & 0 & 0.155 & 2.69 & -0.145 & 0.59 & 0.687 & 0.638 \\
\hline LLNL & $082697 \mathrm{C} 2$ & 60 & 333 & 5.00 & 0 & 0.776 & 6.53 & -0.105 & 0.393 & 0.448 & 0.407 \\
\hline LLNL & $110497 \mathrm{C} 2$ & 90 & 363 & 0.00 & 0.61 & 0.113 & 2.14 & 0.531 & 0.775 & 0.829 & 0.727 \\
\hline LLNL & $103097 \mathrm{C} 1$ & 90 & 363 & 0.00 & 3.05 & 0.564 & 1.72 & 0.584 & 0.759 & 0.766 & 0.655 \\
\hline LLNL & $103197 \mathrm{C} 2$ & 90 & 363 & 0.00 & 3.05 & 0.564 & 1.72 & 0.439 & 0.838 & 0.872 & 0.688 \\
\hline NRC & $\mathrm{C} 22-1$ & 95 & 368 & 25.78 & 0 & 4.000 & 8.2 & & & & 0.916 \\
\hline NRC & $\mathrm{C} 22-2$ & 95 & 368 & 25.78 & 0 & 4.000 & 8.2 & & & & 0.911 \\
\hline NRC & $\mathrm{C} 22-3$ & 95 & 368 & 25.78 & 0 & 4.000 & 8.2 & & & & 0.9 \\
\hline NRC & $\mathrm{C} 22-4$ & 60 & 333 & 25.78 & 0 & 1.000 & 8.2 & & & & 0.911 \\
\hline NRC & $\mathrm{C} 22-5$ & 95 & 368 & 6.44 & 0 & 1.000 & 8.2 & & & & 0.829 \\
\hline NRC & $\mathrm{C} 22-6$ & 60 & 333 & 6.44 & 0 & 1.000 & 8.2 & & & & 0.986 \\
\hline NRC & $\mathrm{C} 22-7$ & 95 & 368 & 0.18 & 0 & 0.028 & 8.2 & & & & 0.854 \\
\hline
\end{tabular}

Table 9b. Corrosion and Threshold Potentials (vs. SHE) Measured by LLNL \& NRC.

\begin{tabular}{|c|c|c|c|c|c|c|c|}
\hline ID & Reference & Correction & Ecorr & Epit - low & Epit - high & Epass & Comments \\
\hline & & $\mathrm{V}$ & $\mathrm{V}$ vs. SHE & V vs. SHE & V vs. SHE & V vs. SHE & \\
\hline $090996 \mathrm{C} 1$ & $\mathrm{Ag} / \mathrm{AgCl} / \mathrm{KCl}$ & 0.1297 & -0.0243 & 0.4417 & 0.4417 & 0.5497 & inconsistent \\
\hline $103397 \mathrm{C} 1$ & $\mathrm{Ag} / \mathrm{AgCl} / \mathrm{KCl}$ & 0.1297 & -0.0293 & 0.7577 & 0.8627 & 0.7927 & \\
\hline $102497 \mathrm{C} 2$ & $\mathrm{Ag} / \mathrm{AgCl} / \mathrm{KCl}$ & 0.1297 & -0.0323 & 0.7577 & 0.9147 & 0.7407 & \\
\hline $102797 \mathrm{C} 1$ & $\mathrm{Ag} / \mathrm{AgCl} / \mathrm{KCl}$ & 0.1297 & -0.0723 & 0.5527 & 0.7837 & 0.2877 & inconsistent \\
\hline $081997 \mathrm{C} 1$ & $\mathrm{Ag} / \mathrm{AgCl} / \mathrm{KCl}$ & 0.1297 & -0.0153 & 0.7197 & 0.8167 & 0.7677 & \\
\hline $082697 \mathrm{C} 2$ & $\mathrm{Ag} / \mathrm{AgCl} / \mathrm{KCl}$ & 0.1577 & 0.0527 & 0.5507 & 0.6057 & 0.5647 & inconsistent \\
\hline $110497 \mathrm{C} 2$ & $\mathrm{Ag} / \mathrm{AgCl} / \mathrm{KCl}$ & 0.1297 & 0.6607 & 0.9047 & 0.9587 & 0.8567 & \\
\hline $103097 \mathrm{C} 1$ & $\mathrm{Ag} / \mathrm{AgCl} / \mathrm{KCl}$ & 0.1297 & 0.7137 & 0.8887 & 0.8957 & 0.7847 & \\
\hline $103197 \mathrm{C} 2$ & $\mathrm{Ag} / \mathrm{AgCl} / \mathrm{KCl}$ & 0.1297 & 0.5687 & 0.9677 & 1.0017 & 0.8177 & \\
\hline $\mathrm{C} 22-1$ & $\mathrm{SCE}$ & 0.1861 & & & & 1.1021 & \\
\hline $\mathrm{C} 22-2$ & $\mathrm{SCE}$ & 0.1861 & & & & 1.0971 & \\
\hline $\mathrm{C} 22-3$ & $\mathrm{SCE}$ & 0.1861 & & & & 1.0861 & \\
\hline $\mathrm{C} 22-4$ & $\mathrm{SCE}$ & 0.2344 & & & & 1.1454 & \\
\hline $\mathrm{C} 22-5$ & $\mathrm{SCE}$ & 0.1861 & & & & 1.0151 & \\
\hline $\mathrm{C} 22-6$ & $\mathrm{SCE}$ & 0.2344 & & - & - & 1.2204 & \\
\hline $\mathrm{C} 22-7$ & $\mathrm{SCE}$ & 0.1861 & & - & & \\
\hline
\end{tabular}


Draft Rev. 5 - J. C. Farmer, LLNL, YMP WP Degradation, Expert Elicitation Panel, Feb. 26, 1998

The probability of initiating localized corrosion are based on the stochastic probability theory of pit initiation, as discussed by Baroux [B. Baroux, "Further Insights on the Pitting Corrosion of Stainless Steels," Chapter 9, Corrosion Mechanisms in Theory and Practice, P. Marcus, J. Oudar, Eds., Marcel Dekker, Inc., New York, NY, pp. 265-309]. First, the expression for the survival probability is:

$\delta P_{S}=1-\bar{\omega} \times \delta S$

where $\delta \mathrm{P}$ is the survival probability (probability of no pitting) of an infinitesimal area $\delta \mathrm{S}$ on a sample of area $\mathrm{S}$. The survival probability of the entire surface $\mathrm{S}$ is then:

$P_{S}=[1-\bar{\omega} \times \delta S] \overline{s S}$

The pit generation rate, PGR, is then defined in terms of the time derivative of the elementary pitting probability:

$$
\begin{aligned}
& \frac{d \bar{\omega}}{d t}=g=P G R \\
& \bar{\omega}=\int_{0}^{t}(P G R) d t
\end{aligned}
$$

We then make the following simplification by assuming that PGR is independent of time and that $\delta \mathrm{S} \sim$ $\mathrm{S}$. While it would be better to avoid such gross over simplification, it does provide some degree of insight into the expected dependence of the survival probability, and the probability of pit initiation, on electrochemical potential. This insight is needed to address the question regarding probability of pitting.

$P_{S} \approx 1-P G R \times t \times S$

The probability of pitting (localized corrosion, LC) is then assumed to be:

$P_{L C^{\prime}} \approx P G R \times t \times S$

It is observed empirically that:

$\ln (P G R) \approx \beta\left(E-E_{p i t}\right)$

Therefore:

$\ln \left(\frac{P_{L C, 1}}{P_{I C, 2}}\right) \approx \ln \left(\frac{P G R_{1}}{P G R_{2}}\right) \approx \beta\left(E_{1}-E_{2}\right)$

We can estimate the empirical constant $\beta$ as: 
$\beta=\frac{\ln \left(P_{L C, 1} / P_{L C, 2}\right)}{\left(E_{1}-E_{2}\right)}$

Now, for illustration, consider a hypothetical case where the repassivation potential is assumed to be the point at which there is a $5 \%$ chance of initiating localized corrosion. Furthermore, assume that the average repassivation potential is $800 \mathrm{mV}$ vs. SHE, and that the observed scatter around the averate 1 $50 \mathrm{mV}$. The probability of initiating localized corrosion at $800 \mathrm{mV}$ vs. SHE is assumed to be $5 \%$, and the probability of initiating localized corrosion at $800-50 \mathrm{mV}$ vs. SHE is assumed to be $1 \%$. In this case,

$$
\beta=\frac{\ln (5 / 1)}{(800 m V-750 m V)} \approx 0.032 m V^{-1}
$$

The CDF based upon these simplification and assumptions are summarized in Table 10a, where the recommended case is Case 3. It should be noted that the maximum probability of pitting is believed to be less than a $15 \%\left(99^{\text {th }}\right.$ percentile, $\left.\mathrm{pH} 2.5,640 \mathrm{mV}\right)$, with typical values of $0.01-2.12 \%$ (Table $10 \mathrm{~b}$ ).

\section{4) What is the localized corrosion rate of the C-22 inner barrier?}

The expert assessments to date have provided two alternative ways to model localized corrosion of the inner barrier: a) "exponential" pit growth law, and b) "logarithmic" pit growth law: Exponential crevice growth law is expressed as follows:

$p=B \times t^{n}$

where $\mathrm{p}$ is the crevice depth, $\mathrm{B}$ is a constant, $\mathrm{t}$ is time, and $\mathrm{n}$ is an exponent. Distributions for the constants $B$ and $n$ have been provided. A crevice corrosion model suggested recently by LLNL belongs to this type ( $n=1 / 2$ corresponding to a diffusion-controlled penetration rate). Logarithmic crevice growth law is expressed as follows:

$$
p=k \times \exp \left[\frac{Q}{T}\right] \times \log [t]-x_{0}
$$

where $\mathrm{k}, \mathrm{Q}$ and $\mathrm{x}_{0}$ are constants, $\mathrm{T}$ is temperature, and $\mathrm{t}$ is time. Distributions for the constants $\mathrm{k}, \mathrm{Q}$ and $\mathrm{x}_{0}$ have been provided. Please express your assessment of corrosion rate using either of these functional forms (or another of your choice). Please consider the following conditions:

$\mathrm{T}=25^{\circ} \mathrm{C}$

1) $\mathrm{pH} 2.5$ and potential of $340 \mathrm{mV}_{\mathrm{SHE}}$ and $640 \mathrm{mV}_{\mathrm{SHE}}$

2) $\mathrm{pH} 3-10$ and potential of $340 \mathrm{mV}_{\mathrm{SHE}}$ $\mathrm{T}=50^{\circ} \mathrm{C}$

1) $\mathrm{pH} 2.5$ and potential of $340 \mathrm{mV}_{\mathrm{SHE}}$ and $640 \mathrm{mV}_{\mathrm{SHE}}$

2) pII 3-10 and potential of $340 \mathrm{mV}_{\mathrm{SHE}}$

$\mathrm{T}=100^{\circ} \mathrm{C}$

1) $\mathrm{pH} 2.5$ and potential of $340 \mathrm{mV}_{\mathrm{SHE}}$ and $640 \mathrm{mV}_{\mathrm{SHE}}$

2) $\mathrm{pH} 3-10$ and potential of $340 \mathrm{mV}_{\text {SHE }}$ 
Uncertainties in the coefficients of the growth laws should be expressed by, as a minimum, the 0th and $100 t h$ percentile values along with the median, 5th percentile and 95th percentile values.

\section{Response:}

While the logarithmic expression has some very attractive features, it has a severe inconsistency at zero time (undefined logarithim, $\log (0)$ ). Therefore, this member of the Panel prefers the exponential form. The penetration rates for localized corrosion shown in Tables 12 are based on Asphahani's data for Alloys C-22 and C-276, which are summarized in Tables 4 and 11, respectively. These data can also be found in Tables 22 and 23 of Gdowski's degradation mode survey, respectively [G. E. Gdowski, "Survey of Degradation Modes of Four Nickel-Chromium-Molybdenum Alloys," UCRLID-108330, March, 1991, pp. 30-31]. Specific points used to generate Table 12 are in bold-face type. In the case of localized corrosion at $340 \mathrm{mV}$ vs. SHE, it was assumed that the penetration rates were similar to those observed for Alloy C-22 in simulated crevice solutions (accelerated passive corrosion in $10 \mathrm{wt} . \% \mathrm{FeCl}_{3}$ ). In the case of localized corrosion at $640 \mathrm{mV}$ vs. SHE, it was assumed that the penetration rates were similar to those observed for Alloy 625 (active crevice in $10 \mathrm{wt} . \% \mathrm{FeCl}_{3}$ and and active pitting corrosion in "green death" solution). The apparent activation energy is assumed to be $20 \mathrm{kcal} / \mathrm{mol}$, which is close to that observed for many chemical reactions. Note the rapid wall penetration predicted at high applied potential (640 mV vs. NHE) and low $\mathrm{pH}(2.5)$.

In regard to pit penetration rates, it must be noted that the current elicitation does not deal with the issue of "stiffling" which leads to the death or a propagating pit. It must be noted that the pit can "die" if the depth becomes so great that the current density at the base of the pit falls below the passive current density. The importance of such "stifling" has also been pointed out by Scully [J. R. Scully, "Appendix D, Elicitation Interview Summaries," Waste Package Degradation Expert Elicitation Project Final Report, K. J. Coppersmith, R. C. Perman, M. Pendleton, J. L. Younker, Civilian Radioactive Waste Management System Management and Operating Contractor, Geomatrix Consultants, San Francisco, CA, August 15, 1997, pp. JS 1-30]. In the case of pit propagation in carbon steel, Marsh gives the following criteria based upon the passive current density, $\mathrm{i}_{\text {pass }}$ [G. P. Marsh, K. J. Taylor, Z Sooi, "The Kinetics of Pitting Corrosion of Carbon Steel," SKB Technical Report 88-09, Swedish Nuclear Fuel and Waste Management Company (SKB), Box 5864, S-102 48, Stockholm, 1988, 39 p.]:

$$
\frac{i_{\text {pass }}}{4 F} \leq\left. D \frac{\partial C(x, t)}{\partial x}\right|_{r=0}
$$

It was noted that careful measurements of $i_{\text {pass }}$ are required for any theoretical analysis. The critical concentration gradient across the pit is estimated to be:

$$
\left.\frac{\Delta C}{\Delta x}\right|_{\text {critical }} \geq \frac{i_{p a s s}}{4 F D}
$$

A typical passive current density for Alloy C-22 determined with cyclic polarization is $\sim 10^{-6} \mathrm{~A} / \mathrm{cm}^{2}$. Given a typical liquid-phase diffusivity of $\sim 10^{-5} \mathrm{~cm}^{2} / \mathrm{sec}$, and Faraday's constant of $9.64846 \times 10^{4}$ C/equiv $\left(\sim 10^{5} \mathrm{C} /\right.$ equiv), the critical concentration gradient across the pit is estimated to be $\sim 10^{-6}$ equiv/ $\mathrm{cm}^{4}$. Since the maximum possible pit depth is $2 \mathrm{~cm}$ (wall thickness), a critical saturation 
Draft Rev. 5-J C. Farmer, LLNL, YMP WP Degradation, Expert Elicitation Panel, Feb 26, 1998

concentration at the base of the pit is calculated to be $\sim 2 \times 10^{-6}$ equiv/ $/ \mathrm{cm}^{3}\left(\sim 6.67 \times 10^{-4} \mathrm{~mol} / \mathrm{kg}\right.$ for trivalent dissolved metal such as chromium). If any dissolved species at the base of the pit has a solubility less than this limiting value, the pit will die before wall penetration is achieved. From the Pourbaix diagram of chromium (calculated by Marcel Pourbaix), it can be seen that the estimated concentration of $\mathrm{Cr}_{2} \mathrm{O}_{3}$ is $10^{-11}$ to $10^{-12} \mathrm{~mol} / \mathrm{kg}$ at saturation, whereas the estimated concentration of the more soluble $\mathrm{Cr}(\mathrm{OH})_{3}$ is $10^{-6}$ to $10^{-7} \mathrm{~mol} / \mathrm{kg}$ at saturation. Clearly, in either case, the pit will stifle (die) before a pit depth of $2 \mathrm{~cm}$ is achieved. Predicted pit depths greater than $2 \mathrm{~cm}$ are not realistic.

Table 10a Estimated CDF Probabilities for Initiation of Localized Corrosion.

\begin{tabular}{|c|c|c|c|}
\hline Case 1: $P=5 \%$ at $E_{\text {pass }} \& \mathrm{P}=1 \%$ at $E_{\text {pass, low }}$ & Environment A & Environment B & Environment C \\
\hline $\mathrm{pH}$ & 2.5 & 2.5 & 5 to 7 \\
\hline $\mathrm{E}(\mathrm{mV}$ vs. SHE) & 340 & 640 & 340 \\
\hline$\beta$ at $25^{\circ} \mathrm{C}$ & $8.05 \times 10^{-3}$ & $8.05 \times 10^{-3}$ & $8.05 \times 10^{-3}$ \\
\hline$\beta$ at $50^{\circ} \mathrm{C}$ & $8.05 \times 10^{-3}$ & $8.05 \times 10^{-3}$ & $8.05 \times 10^{-3}$ \\
\hline$\beta$ at $100^{\circ} \mathrm{C}$ & $8.05 \times 10^{-3}$ & $8.05 \times 10^{-3}$ & $8.05 \times 10^{-3}$ \\
\hline $\mathrm{P}$ at $25^{\circ} \mathrm{C}$ & 0.0368 & 0.4123 & 0.0074 \\
\hline $\mathrm{P}$ at $50^{\circ} \mathrm{C}$ & 0.0824 & 0.9221 & 0.0165 \\
\hline $\mathrm{P}$ at $100^{\circ} \mathrm{C}$ & 0.1843 & 2.0625 & 0.0368 \\
\hline Case 2: $\mathrm{P}=50 \%$ at $\mathrm{E}_{\text {pass }} \& \mathrm{P}=5 \%$ at $\mathrm{E}_{\text {pass, } 10 \mathrm{w}}$ & Environment A & Environment B & Environment C \\
\hline $\mathrm{pH}$ & 2.5 & 2.5 & 5 to 7 \\
\hline $\mathrm{E}(\mathrm{mV}$ vs. SHE) & 340 & 640 & 340 \\
\hline$\beta$ at $25^{\circ} \mathrm{C}$ & $1.15 \times 10^{-2}$ & $1.15 \times 10^{-2}$ & $1.15 \times 10^{-2}$ \\
\hline$\beta$ at $50^{\circ} \mathrm{C}$ & $1.15 \times 10^{-2}$ & $1.15 \times 10^{-2}$ & $1.15 \times 10^{-2}$ \\
\hline$\beta$ at $100^{\circ} \mathrm{C}$ & $1.15 \times 10^{-2}$ & $1.15 \times 10^{-2}$ & $1.15 \times 10^{-2}$ \\
\hline $\mathrm{P}$ at $25^{\circ} \mathrm{C}$ & 0.0449 & 1.4148 & 0.0045 \\
\hline $\mathrm{P}$ at $50^{\circ} \mathrm{C}$ & 0.1419 & 4.4684 & 0.0142 \\
\hline $\mathrm{P}$ at $100^{\circ} \mathrm{C}$ & 0.4480 & 14.1120 & 0.0449 \\
\hline Case 3: $P=50 \%$ at $E_{\text {pass }} \& P=1 \%$ at $E_{\text {pass, low }}$ & Environment A & Environment B & Environment $\mathrm{C}$ \\
\hline $\mathrm{pH}$ & 2.5 & 2.5 & 5 to 7 \\
\hline $\mathrm{E}(\mathrm{mV}$ vs. SHE) & 340 & 640 & 340 \\
\hline$\beta$ at $25^{\circ} \mathrm{C}$ & $7.82 \times 10^{-3}$ & $7.82 \times 10^{-3}$ & $7.82 \times 10^{-3}$ \\
\hline$\beta$ at $50^{\circ} \mathrm{C}$ & $7.82 \times 10^{-3}$ & $7.82 \times 10^{-3}$ & $7.82 \times 10^{-3}$ \\
\hline$\beta$ at $100^{\circ} \mathrm{C}$ & $7.82 \times 10^{-3}$ & $7.82 \times 10^{-3}$ & $7.82 \times 10^{-3}$ \\
\hline $\mathrm{P}$ at $25^{\circ} \mathrm{C}$ & 0.0424 & 0.4427 & 0.0089 \\
\hline $\mathrm{P}$ at $50^{\circ} \mathrm{C}$ & 0.0927 & 0.9678 & 0.0194 \\
\hline $\mathrm{P}$ at $100^{\circ} \mathrm{C}$ & 0.2026 & 2.1154 & 0.0424 \\
\hline
\end{tabular}

Table 10b. Estimated CDF Probabilities (\%) for Initiation of Localized Corrosion - Based on 10a.

\begin{tabular}{|l|c|c|c|c|c|c|c|c|c|}
\hline Percentile $(\%)$ & $\mathrm{A} / 25^{\circ} \mathrm{C}$ & $\mathrm{A} / 50^{\circ} \mathrm{C}$ & $\mathrm{A} / 100^{\circ} \mathrm{C}$ & $\mathrm{B} / 25^{\circ} \mathrm{C}$ & $\mathrm{B} / 50^{\circ} \mathrm{C}$ & $\mathrm{B} / 100^{\circ} \mathrm{C}$ & $\mathrm{C} / 25^{\circ} \mathrm{C}$ & $\mathrm{C} / 50^{\circ} \mathrm{C}$ & $\mathrm{C} / 100^{\circ} \mathrm{C}$ \\
\hline 1 (Case 1) & 0.0368 & 0.0824 & 0.1843 & 0.4123 & 0.9221 & 2.0625 & 0.0074 & 0.0165 & 0.0368 \\
\hline 5 & 0.0396 & 0.0876 & 0.1935 & 0.4275 & 0.9450 & 2.0890 & 0.0082 & 0.0180 & 0.0396 \\
\hline 50 (Case 3) & 0.0424 & 0.0927 & 0.2026 & 0.4427 & 0.9678 & 2.1154 & 0.0089 & 0.0194 & 0.0424 \\
\hline 95 & 0.0437 & 0.1173 & 0.3253 & 1.1501 & 2.7181 & 8.1137 & 0.0067 & 0.0168 & 0.0437 \\
\hline 99 (Case 2) & 0.0449 & 0.1419 & 0.4480 & 1.4148 & 4.4684 & 14.1120 & 0.0045 & 0.0142 & 0.0449 \\
\hline
\end{tabular}


Draft Rev. 5 - J. C. Farmer, LLNL, YMP WP Degradation, Expert Elicitation Panel, Feb. 26, 1998

Table 11. Observed Localized Corrosion Penetration Rates for Alloy 625.

\begin{tabular}{|l|l|l|l|}
\hline Crevice Corrosion & Crevice Corrosion & Pitting Corrosion & Pitting Corrosion \\
\hline $25^{\circ} \mathrm{C}$ & $50^{\circ} \mathrm{C}$ & $25^{\circ} \mathrm{C}$ & $102^{\circ} \mathrm{C}$ \\
\hline $10 \mathrm{wt} \% \mathrm{FeCl}_{3}$ & $10 \mathrm{wt} . \% \mathrm{FeCl}_{3}$ & 7 vol. $\% \mathrm{H}_{2} \mathrm{SO}_{4}+$ & 7 vol. $\% \mathrm{H}_{2} \mathrm{SO}_{4}+$ \\
& & 3 vol. $\% \mathrm{HCl}+$ & 3 vol. $\% \mathrm{HCl}+$ \\
& & 1 wt. $\% \mathrm{FeCl}_{3}+$ & 1 wt. $\% \mathrm{FeCl}_{3}+$ \\
& & 1 wt. $\% \mathrm{CuCl}_{2}$ & 1 wt. $\% \mathrm{CuCl}_{2}$ \\
\hline 38.1 microns $/ \mathrm{yr}$ & 3,150 microns/yr & 7.62 microns $/ \mathrm{yr}$ & $48,060 \mathrm{microns} / \mathrm{yr}$ \\
\hline
\end{tabular}

Table 12. Estimates of the CDF's for Penetration Rate Parameters for Localized Corrosion.

\begin{tabular}{|c|c|c|c|c|c|c|c|}
\hline $\mathrm{pH}=2.5$ & & & & & & & \\
\hline \multicolumn{8}{|l|}{$\mathrm{E}=340 \mathrm{mV}$} \\
\hline Percentile & $n$ & $k($ for $n=1)$ & $\overline{\mathrm{Ea}}$ & $\mathrm{Q}$ & $\begin{array}{c}\text { Depth } \\
\left(1 \mathrm{yr} ; 25^{\circ} \mathrm{C} ; \mathrm{n}=1\right) \\
\end{array}$ & $\begin{array}{c}\text { Depth } \\
\left(1 \mathrm{yr} ; 75^{\circ} \mathrm{C} ; \mathrm{n}=1\right) \\
\end{array}$ & $\begin{array}{c}\text { Depth } \\
\left(1000 \mathrm{yr} ; 60^{\circ} \mathrm{C} ; \mathrm{n}=1\right)\end{array}$ \\
\hline$\%$ & none & microns/yr & $\mathrm{cal} / \mathrm{mol}$ & $\mathrm{K}$ & microns & microns & $\mathrm{cm}$ \\
\hline 0 & 0 & $5.07 \times 10^{12}$ & 5000 & 2500 & 0.01 & 1.7 & 0.0461 \\
\hline 1 & 0.1 & $7.99 \times 10^{12}$ & 10000 & 5000 & 0.02 & 2.6 & 0.0726 \\
\hline 5 & 0.3 & $1.26 \times 10^{13}$ & 15000 & 7500 & 0.03 & 4.2 & 0.1148 \\
\hline 50 & 0.5 & $3.83 \times 10^{13}$ & 20000 & 10000 & 0.10 & 12.7 & 0.3481 \\
\hline 95 & 0.7 & $1.16 \times 10^{14}$ & 25000 & 12500 & 0.31 & 38.5 & 1.0550 \\
\hline 99 & 0.9 & $9.37 \times 10^{14}$ & 30000 & 15000 & 2.50 & 310.4 & 8.5056 \\
\hline 100 & 1 & $7.08 \times 10^{15}$ & 35000 & 17500 & 18.89 & 2345.1 & 64.2713 \\
\hline \multicolumn{8}{|l|}{$\mathrm{pH}=2.5$} \\
\hline \multicolumn{8}{|l|}{$E=640 \mathrm{mV}$} \\
\hline Percentile & $n$ & $k($ for $n=1)$ & $\mathrm{Ea}$ & Q & $\begin{array}{c}\text { Depth } \\
\left(1 \mathrm{yr} ; 50^{\circ} \mathrm{C} ; \mathrm{n}=1\right) \\
\end{array}$ & $\begin{array}{c}\text { Depth } \\
\left(1 \mathrm{yr} ; 102^{\circ} \mathrm{C} ; \mathrm{n}=1\right) \\
\end{array}$ & $\begin{array}{c}\text { Dcpth } \\
\left(1000 \mathrm{yr} ; 60^{\circ} \mathrm{C} ; \mathrm{n}=1\right) \\
\end{array}$ \\
\hline$\%$ & none & microns/yr & $\mathrm{cal} / \mathrm{mol}$ & $\mathrm{K}$ & microns & microns & $\mathrm{cm}$ \\
\hline 0 & 0 & $2.42 \times 10^{15}$ & 5000 & 2500 & 87 & 6360 & 22 \\
\hline 1 & 0.1 & $3.82 \times 10^{15}$ & 10000 & 5000 & 137 & 10018 & 35 \\
\hline 5 & 0.3 & $6.04 \times 10^{15}$ & 15000 & 7500 & 217 & 15855 & 55 \\
\hline 50 & 0.5 & $1.83 \times 10^{16}$ & 20000 & 10000 & 657 & 48060 & 166 \\
\hline 95 & 0.7 & $5.55 \times 10^{16}$ & 25000 & 12500 & 1990 & 145677 & 504 \\
\hline 99 & 0.9 & $8.79 \times 10^{16}$ & 30000 & 15000 & 3150 & 230555 & 798 \\
\hline 100 & 1 & $6.64 \times 10^{17}$ & 35000 & 17500 & 23803 & 1742155 & 6031 \\
\hline \multicolumn{8}{|l|}{$\mathrm{pH}=3-10$} \\
\hline \multicolumn{8}{|l|}{$\mathrm{E}=340 \mathrm{mV}$} \\
\hline Percentile & $\mathrm{n}$ & $\mathrm{k}($ for $\mathrm{n}=1)$ & $\mathrm{Ea}$ & $Q$ & $\begin{array}{c}\text { Depth } \\
\left(1 \mathrm{yr} ; 25^{\circ} \mathrm{C} ; \mathrm{n}=1\right)\end{array}$ & $\begin{array}{c}\text { Depth } \\
\left(1 \mathrm{yr} ; 75^{\circ} \mathrm{C} ; \mathrm{n}=1\right)\end{array}$ & $\begin{array}{c}\text { Depth } \\
\left(1000 \mathrm{yr} ; 60^{\circ} \mathrm{C} ; \mathrm{n}=1\right)\end{array}$ \\
\hline$\%$ & none & microns/yr & $\mathrm{cal} / \mathrm{mol}$ & $\mathrm{K}$ & microns & microns & $\mathrm{cm}$ \\
\hline 0 & 0 & $5.07 \times 10^{12}$ & 5000 & 2500 & 0.01 & 1.7 & 0.0461 \\
\hline 1 & 0.1 & $7.99 \times 10^{12}$ & 10000 & 5000 & 0.02 & 2.6 & 0.0726 \\
\hline 5 & 0.3 & $1.26 \times 10^{13}$ & 15000 & 7500 & 0.03 & 4.2 & 0.1148 \\
\hline 50 & 0.5 & $3.83 \times 10^{13}$ & 20000 & 10000 & 0.10 & 12.7 & 0.3481 \\
\hline 95 & 0.7 & $1.16 \times 10^{14}$ & 25000 & 12500 & 0.31 & 38.5 & 1.0550 \\
\hline 99 & 0.9 & $9.37 \times 10^{14}$ & 30000 & 15000 & 2.50 & 310.4 & 8.5056 \\
\hline 100 & 1 & $7.08 \times 10^{15}$ & 35000 & 17500 & 18.89 & 2345.1 & 64.2713 \\
\hline
\end{tabular}




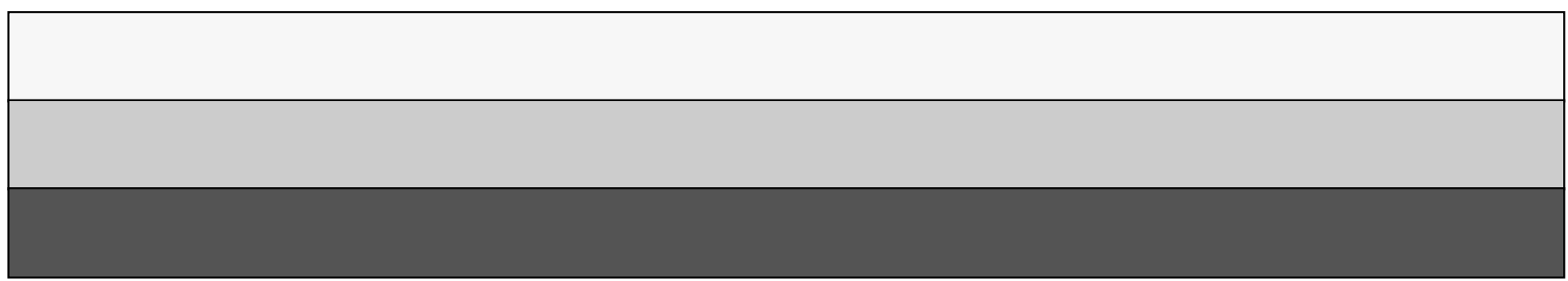

